\title{
قلق الاختبار باستخدام التابلت لدى طلبة المرحلة الثانوية العامة
}

\section{إعداد}

\section{إيناس محمد صفوث خريبه \\ أستاذ علم النفس التربوي المساعد \\ كلية التربية- جامعة الزقازيق}

المقدمة:

يخوض طلبة المرحلة الثانوبـة العامـة تجربـة جديدة في نظام تقوبم الاختبارات التحصيلية النهائية والقائم على التكنولوجيا متمثنًا في تتاول الاختبار باستخدام التابلت، مما ترتب عليه معاناتهح من العديد من التعقيدات والمشـكلات المصـاحبة لتطبيـق هذه التجربـة وعدم الوضـوح الكافي لـدى الكثيـر مـنهم عـن طبيعتها، وكذلك مواجهة البعض لمواقف يشعرون حيالها بتهديد حياتهم الدراسية مما يتسبب في زيادة Tablet-based test قلقهم تجاه نجاحهم الأكاديمي؛ وبالتالي قد ينتج عنه قلق الاختبار باستخدام التابلت .anxiety

ويعد التقييم الإلكتروني من أحدث نظم التقييم في مصر حيث تم تطبيقه لأول مرة على طلبة الصف

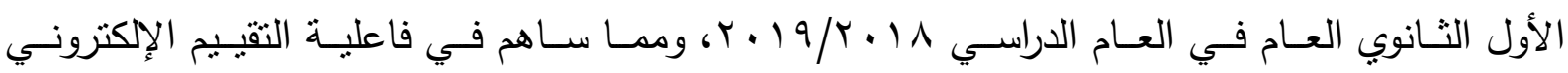
والاختبارات الإكترونية التطور الحادث في نظم البيانات وتكنولوجيا المعلومات. والتقييم الإككتروني هو عملية تقييم مستمرة تشتخدم تكنولوجيا المعلومات والاتصالات لتقديم أنشطة التقييم وتسـجيل اسـتجابات الطلبـة وتسـاعد الطلبـة على الابتعـاد عن البيئة النمطيـة في الاختبـارات الورقيـة .(Hettiarachchi, Huertas \& Mor, 2013, p. 5)

وتعد الاختبارات الإكترونية من أحدث التوجهات في مجال التقويم النفسي والتربوي حيث ثقدم من خلال الكمبيوتز - أو التابلت، وذلك من خلال اختبارات قد تكون لفظية أو مصورة أو مزبج من النمطين، وقد تكون موضوعية أو مقالية أو مزبج من النوعين. وتعد لـدرجات الاختبـار أهميـة كبيـرة في التطسور الأكـاديمي للطلبـة ممـا يضـعهم تحـت ضـغوط هائلــة للحصول على درجات مرتفعة في الاختبار ؛ وقد استُخدم مؤخرًا التابلت المدرسي في تقويم طلبة الصفين الأول والثاني الثانوي العـام تمهيدًا لاستخدامه في تقويم جميع الطلبـة الملتحقين بـالفرق الثلاث للتعليم 
الثانوي العام بمصر؛ ومن ثم، فقد يكون قلق تتاول الاختبار باستخدام التابلت خبرة عامة في المجتمع

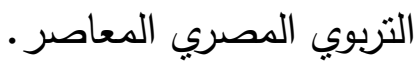

وهناك العديد من البحوث والدراسات التي أجريت حول العلاقة الارتباطية بين قلق الاختبار وغيره من المتغيرات، فقد فحص (2017) Lotz \& Sparfeldt قلق الاختبار كحالة لدى طلبة الجامعة، وتبين أنه يزيد في الاختبارات النهائية مع اقتراب موعد الاختبار.

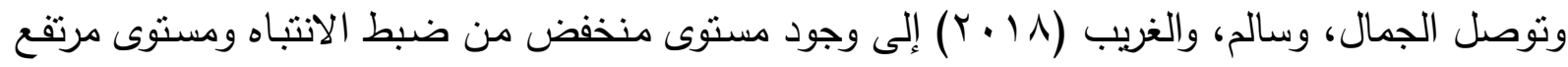

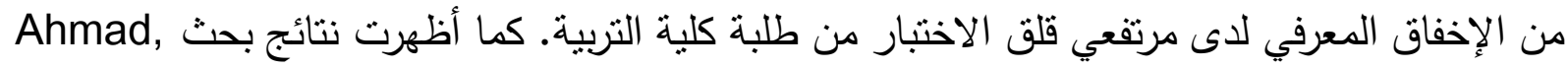
وجود علاقة سالبة دالـة إحصائيًا بين قلق الاختبار والتحصيل الأكاديمي. كذلك توصل (2019) Cipra, \& Muller-Hilke إلى ارتباط أسلوب التعلم السطحي بقلق الاختبار وأن طلبة كلية الطب ذوي أسلوب التعلم الاستراتيجي كانوا الأقل قلقًا والأكثر نجاحًا أكاديميًا. Vaz, Pothiyil, George, وقامت بعض البحوث بقياس مستوى قلق الاختبار حيث كثفت نتائج بحث (2018) (أن معظم عينة البحث لديها مستوى منخفض من قلق

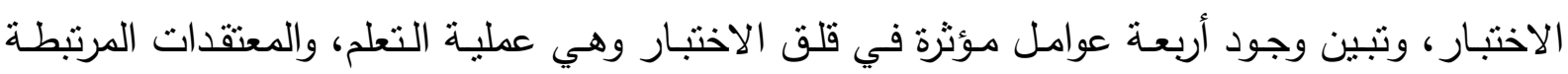
بالاختبار، ونمط التعلم، والتوقعت المرتفعة المرتبطة بالمخرجات التعليمية.

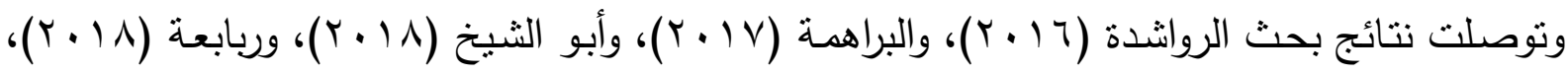

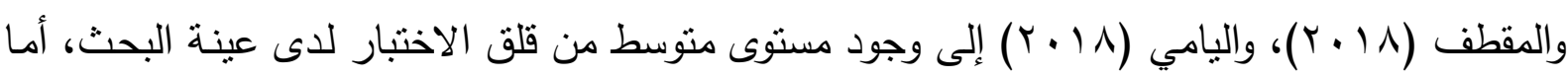

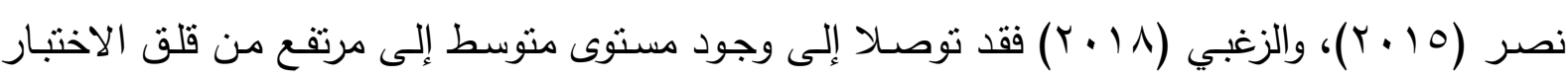
لاى طلبة المرحلة الأساسية العليا.

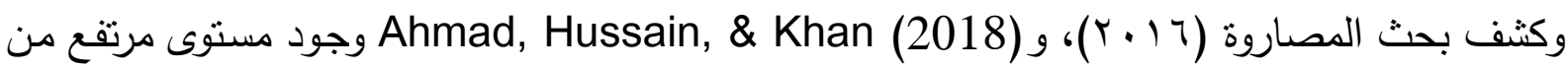
قلق الاختبار . كما نوصل (2019) Al-Sahman إلى أن معظم الطلبة كان لديهم مستوى مرتفع من

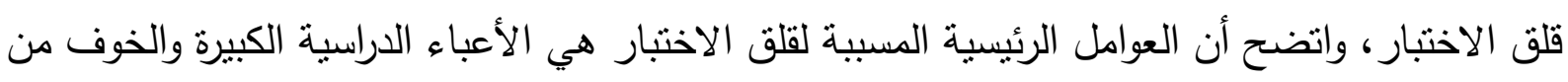
الفنشل أثناء الاختبار والاستذكار طوال ليلة الاختبار .

Martin \& Naziruddin (2020) وفيما يخص علاقة قلق الاختبار ببعض المتغيرات الديموجرافية قام

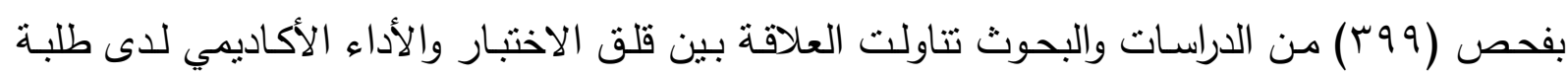

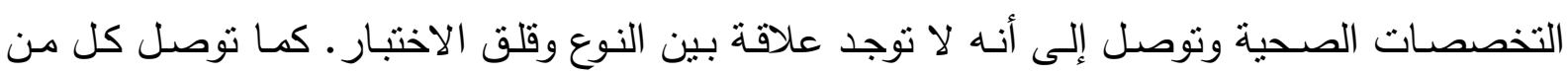

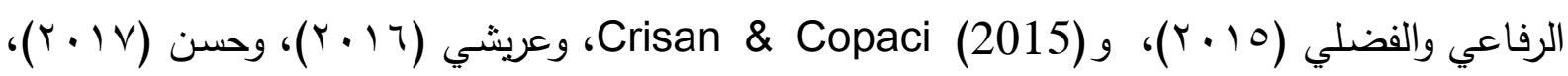

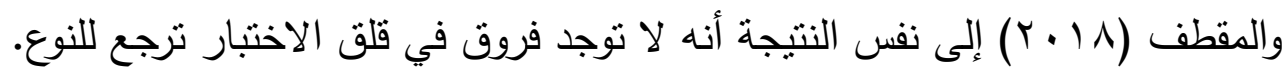




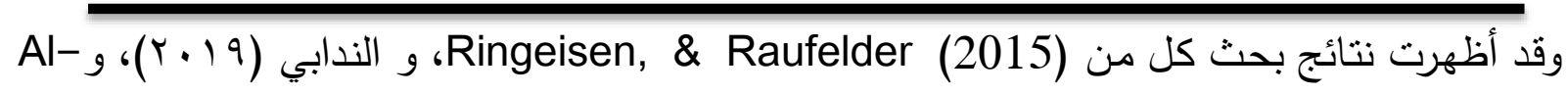

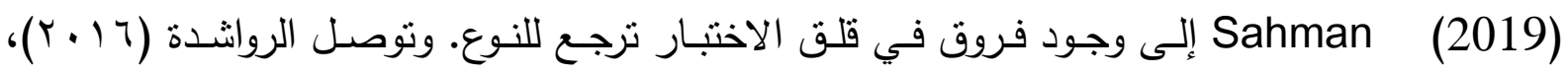
و Stang, Altiere, Ives, \& Dubois (2020) إلى وجود فروق في مستوى قلق الاختبار تعزى تلإن

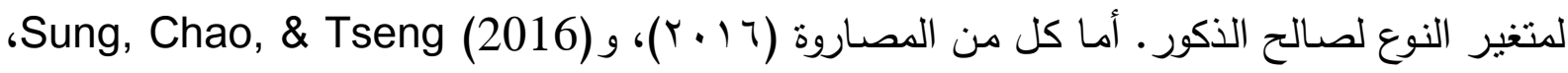

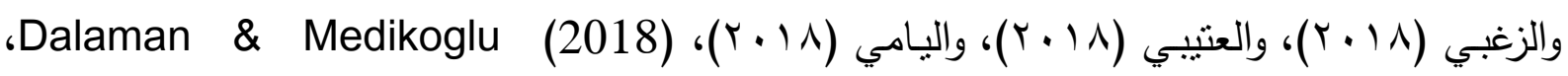
و Mano, Gibler, Mano, \& Beckman (2018)، و (2018)، (Sari, Bilek, \& Celik، و فقد نوصلوا إلى وجود فروق في مستوى قلق الاختبار تعزى للنوع لصالح الإناث.

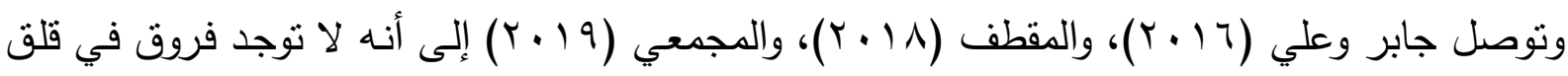

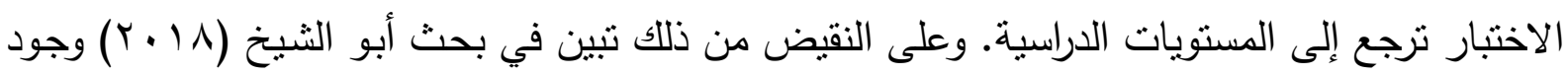

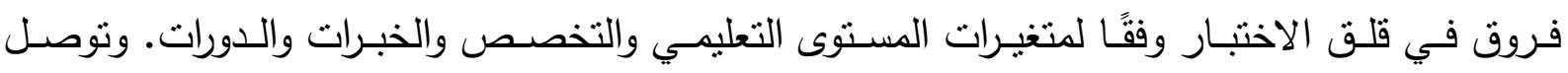
Dalaman \& Medikoglu (2018)

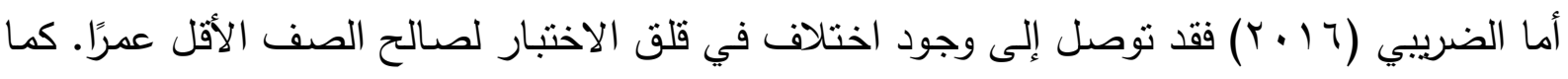

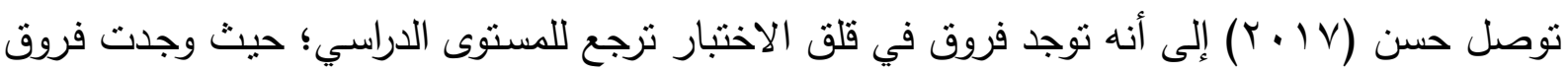

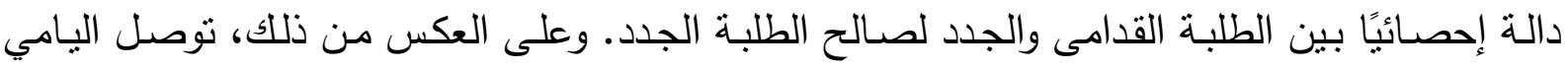

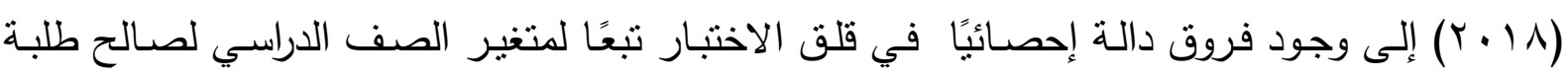
الصف الثالثة الثانوي؛ أي لصالح المستوى الدراسي الأعلى.

وكثفت نتائج بحث الندابي (9 ( ب) اختلاف مستوى قلق الاختبار باختلاف البيئة الجغرافية. من العرض السابق يتضح تتاقض نتائج البحوث والدراسات التي تتاولت قلق الاختبار فيما يخص مستوى

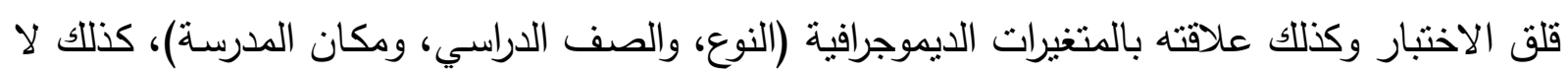

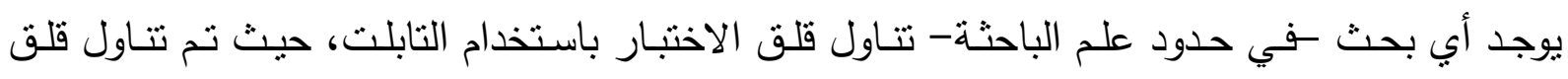

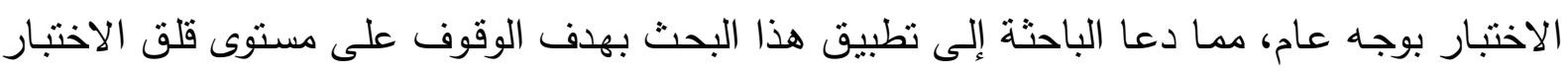

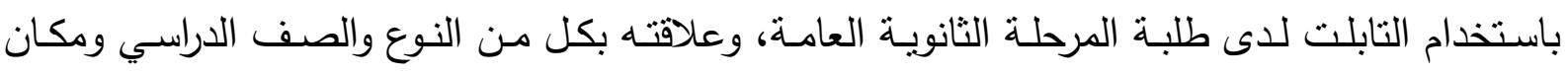
المدرسة.

يتعرض الطلبة بداية من مراحل تعليمهم الأول بالروضة والمدرسة الابتدائية وحتى المرحلة الجامعية لعدد

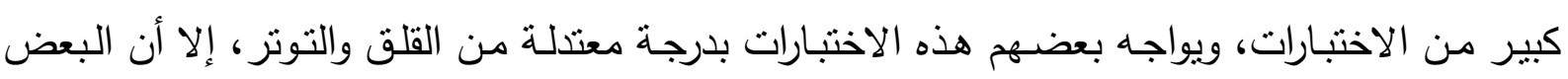


الآخر قد يواجهونها بالقلق المرتفع غير المقبول الذى قد يؤثز على أدائهم فيها، وبالتالي قد ينعكس سلبًا على تقدّمهم الدراسي.

ويتجلى قلق الاختبار -في الوقت الراهن - في مرحلة التعليم الثانوي العام لأنها المرحلة الحرجة لتحديد مسار ومستقبل الطلبة التعليهي والمهني، كما أن طلبة المرحلة الثانويـة العامـة يواجهون تحديات نظام التقييم الجديد باستخدام التابلت مما يجعلهم يتعرّضون لضغوط نفسية ومدرسية وأسرية عديدة. وبما أن درجات الاختبار لها أهمية كبيرة في النجاح الأكاديمي والمهني، فإن ذلك يجعل الطلبة تحت ضغوط هائلة للحصول على درجات مرتفعة في الاختبار؛ ومن ثم أصبح قلق تتاول الاختبار باستخدام التابلت خبرة عامة في المجتمع التربوي المعاصر •

ويميل بعض الطلبة لتتاول الاختبارات باستخدام التابلت نظرًا لما يرونه فيها من مميزات وخصوصًا احتمالية الحصول على درجات أعلى في التحصيل الدراسي، بينما يميل البعض الآخر إلى تتاول اختبارات الورقة والقلم، ومن هنا جاء البحث الحالي لدراسة قلق تتاول الاختبار باستخدام التابلت. ويُعد الموضوع الذي يتتاوله البحث الحالي من الموضوعات المهمة في مجال علم النفس، وخصوصًا في مجال علم النفس المعرفي؛ حيث يعاني بعض الطلبة من قلق الاختبار باستخدام التابلت نظرًا لما يشهده نظام التقييم بالمرحلة الثانوية من تغيّرات كبيرة وجذرية. ومن ثم ينبغي تحديد العوامل التي تتؤثر على تتاول الطلبة للاختبار باستخدام التابلت ومنها قلق الاختبار حيث قد يؤثز قلق تتاول الاختبار باستخدام التابلت سلبًا وقد يعيق قدرة الطلبة على الأداء بشكل جيد بالرغم من نوافر المهارة والمعرفة لديهم. فقد توصل (2015) Crisan \& Copaci C Cئى وجود ارتباط سالب دال إحصـئًا بين قلق الاختبار Morosanova, Fomina, والأداء الأكاديمي لدى تلاميذ المرحلة الابتدائية من عمر (11). كما توصل Filippova (2020) \& إلى وجود علاقة ارتباطية سالبة بين قلق الاختبار والأداء الأكاديمي لدى الطلبة

وقد توصل حسانين والثهري (T ( ا ب) إلى فعالية التقويم الإكتروني في خفض قلق الاختبار وزيادة الدافع للإنجاز الأكاديمي لدى الطلبة المعلمين بنجران بالمملكة العربية السعودية.

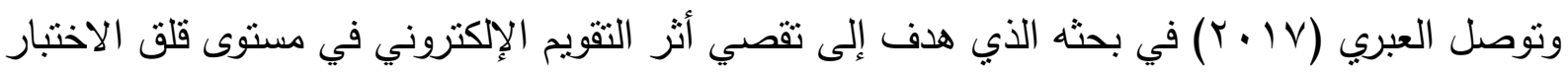
لدى طلاب الصف الثامنة إلى وجود تأثير دال إحصائيًا للتقويم الإلكتروني في خفض قلق الاختبار . كما هدف بحث الدلالعة، وعبابنة، والزبون (9 ( ب) إلى معرفة أثز الاختبارات الإلكترونية على قلق الاختبار لدى طلبة الجامعة الأردنية وأظهرت النتائج أن الطلبة ذوب قلق الاختبار المرتفع أداؤهم على 
الاختبار الإلكتروني أفضل من أدائهم على الاختبار الورقي، وأن الاختبارات الإكترونية أفضل من الاختبارات الورقية في تخفيضها لنسبة القلق مما يسهم في زيادة التحصيل. ومن العرض السابق يمكن صياغة مشكلة البحث في الأسئلة التالية:

ا - ما مستوى قلق الاختبار باستخدام التابلت لدى طلبة المرحلة الثانوية العامة؟ ץ - هل يختلف قلق الاختبار باستخدام التابلت باختلاف النوع (ذكور - إناث) لدى طلبة المرحلة الثانوية العامة ؟ r- هل يختلف قلق الاختبار باستخدام التابلت باختلاف الصف الدراسي (الأول - الثاني) لدى طلبة المرحلة الثانوبة العامة؟ ع - هل يختلف قلق الاختبار باستخدام التابلت باختلاف مكان المدرسة (الحضر - الربف) لدى طلبة المرحلة الثانوبة العامةٌ

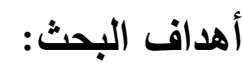
يهذف البحث الحالي إلى : 1- التعرف على مستوى قلق الاختبار باستخدام التابلت لاى طلبة المرحلة الثانوبة العامة. r- التعرف على الفروق في قلق الاختبار التي تعزى للنوع (ذكور - إناث) لدى طلبة المرحلة الثانوية العامة. ب- التعرف على الفروق في قلق الاختبار التي تعزى للصف الدراسي (الأول - الثاني) لدى طلبة المرحلة الثانوبة العامة. ع - التعرف على الفروق في قلق الاختبار التي تعزى لمكان المدرسة (حضر - ريف) لدى طلبة المرحلة الثانوية العامة. أهمبة البحث:

قد تفيد النتائج التي يتوصل لها البحث الحالي في وقوف القائمين على العملية التعليمية بالمرحلة الثانوية في التعرف على مردود الاختبار باستخدام التابلت على نفسية الطلبة من حيث مستوى القلق لديهم، مما قد يحثهم على تعديل أو تطوير آلية تتاول الاختبارات بما لا يسبب قلقًا كبيرًا لدى الطلبة. بالإضافة لذلك قد تقيد نتائج البحث الحالي في إبراز أهمية تدريب طلبة الصف الأول الثانوي العام على تتاول بعض الاختبارات الفصلية عن طريق التابلت لتزداد خبرتهم به مما بعمل على تخفيض قلق الاختبار لديهم في الاختبار النهائي. 
كذللك قد تفبد نتائج البحث الحالي في دق ناقوس الخطر لما يعاني منه الريف المصري من ضعف في الخدمات والبنية التحتية التكنولوجية المواتية لنجاح الاختبارات باستخدام التابلت، وبالتالي العمل على تقديم خدمات أفضل. حدود البحث:

الحدود المنهجية: يتحدد البحث الحالي بإجراءات المنهج الوصفي (الارتباطي) على عينة البحث الحالي. الحدود الموضوعية: يتحدد البحث الحالي بدراسة متغير قلق الاختبار باستخدام التابلت وبعض المتغيرات الديموجرافية. الحدود البشرية: يتحدد البحث الحالي بعينة من طلاب وطالبات الصفين الأول والثاني الثانوي العام بمدينة الزقازيق والمراكز والقرى المجاورة لها. الحدود الزمنية والمكانية: تم تطبيق مقياس قلق الاختبار باستخدام التابلت على طلبة الصفين الأول

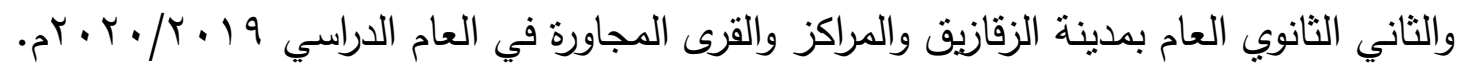
مصطلحات البحث:

قلق الاختبار باستخدام التابلت Tablet-based test anxiety: تعرّف الباحثة قلق الاختبار باستخدام التابلت بأنه: توتز موقفي ينتاب طالب المرحلة الثانوية العامة قبـل أو أنتـاء تتـاول الاختبـارات النهائيـة باسـتخدام التابلت، مدـا يتسـبّب في صـوبة تركيزه أثتـاء أداء الاختبار أو تداخل المعلومات أو صعوبة استرجاعها، وينتج عنه شعوره بالضيق والتوتر ، وظهور بعض الأعراض الفسيولوجية المصاحبة عليه.

ولقلق الاختبـار باسـتخدام التابلت ثلاثة أبعـاد هـي: البعد المعرفي؛ ويتمثّل في شـور الطالب

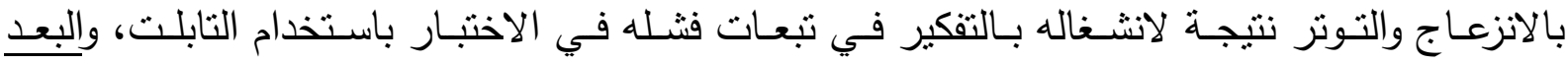
الانفعـالى؛ ويتمنّل في شـور الطالب بالضـيق والخـوف مـن تتـاول الاختبـار باستخدام التابلت، والبعد الفسيولوجي؛ ويتمنّل في التغيرات الفسيولوجية السلبية لاى الطالب والمصاحبة للاختبار باستخدام التابلت. ويُقاس بمجموع الدرجات التي يحصل عليها الطالب في مقياس قلق الاختبار باستخدام التابلت من إعداد الباحثة. الإطار النظري: - (النظ: قلق الاختبار باستخدام التابلت Tablet-based test anxiety: الاختبار الإلكتروني: 
الاختبار الإلكتروني هو عملية تقويم مستمرة مقننة تهدف إلى قياس أداء الطالب إلكترونيًا عن

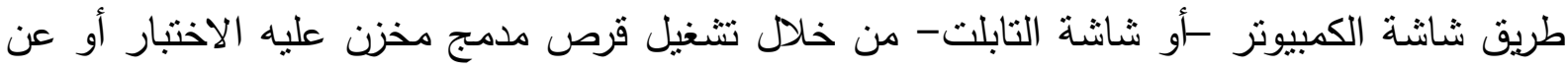

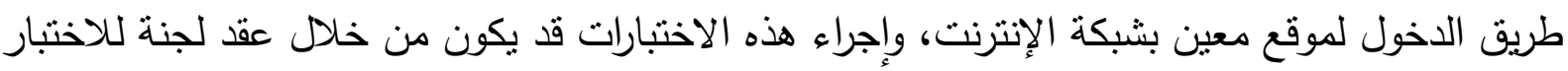

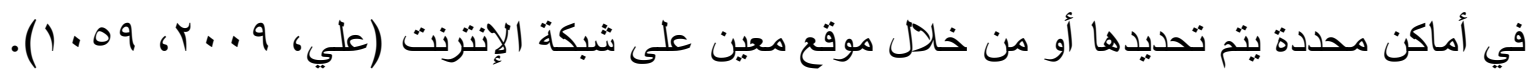
والاختبار الإكتروني هو اختبار تحصيلي يضم عددًا من الأسئلة المتعلقة بالمنهج ويتم عرضها للطالب باستخدام أحد برامج الحاسوب وفق آلية تقويمية معينة ويقوم الطالب بحلها بحيث يستطيع أن يقيم

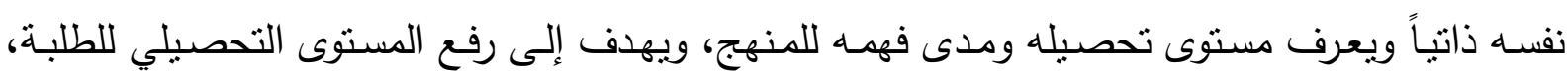
وتجديد وتطوير أنظمة الاختبارات التحصيلية، وتطبيق الطلبة لاستراتيجية التعلم الذاتي، وإثارة دافعيتهم

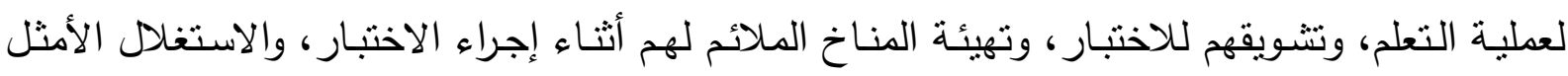

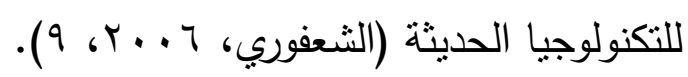
مميزات الاختبار باستخدام التابلت:

ترجع أهية الاختبارات الإلكترونية -منل الاختبار باستخدام التابلت- إلى إمكانياتها المتعددة مثل تتوع الأسئلة وإمكانية عرض ملفات صوت ومقاطع فيديو وصور ثابتة ونصوص، وكذلك تحديد وقت الإنت

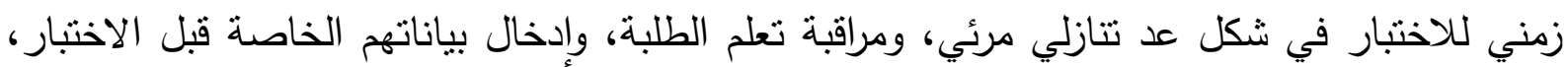
واختبار جوانب معينة من المعرفة والمهارات التي يصعب قياسها باستخدام الاختبارات الورقية؛ فالاختبار

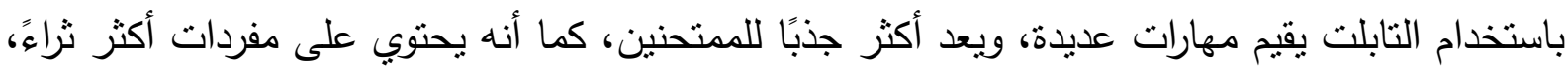

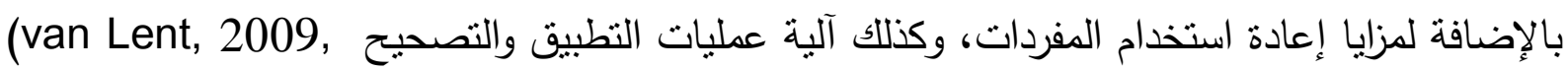

وترى الباحثة أن الاختبارات باستخدام التابلت تمتاز بأنها تعد تجديدًا وابتكارًا واستحداثًا في أنظمة

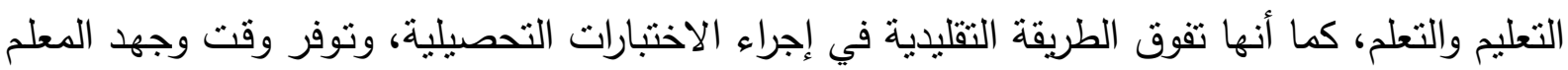
في المراقبة وتصحيح أسئلة الاختبار ، وتقلل من التكلفة المالية اللازمة لشراء الأدوات المكتبية والأوراق

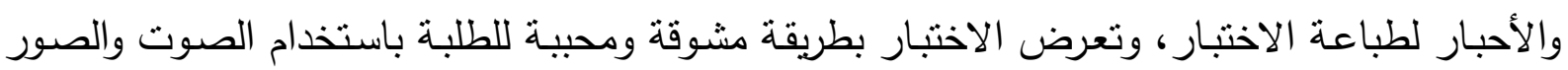

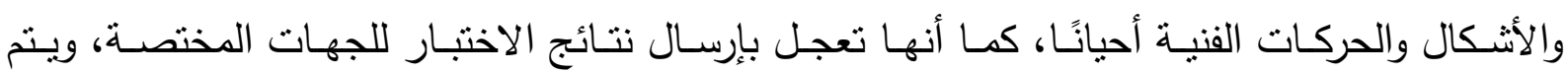

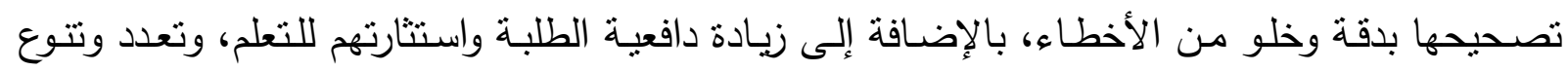

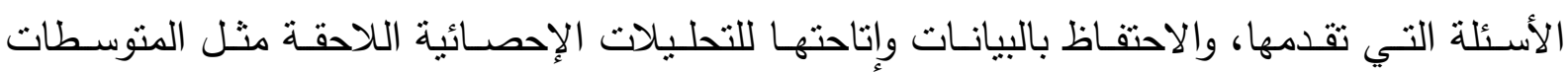
ومعاملات التمييز والسهولة والصعوبة مما يسهم في سهولة استخدام البيانات وتوزيعها وكذلك في إعداد الادئه

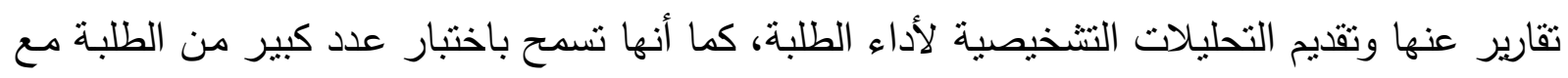


سـهولة تصـيح الاستجابات عن طريـق التابلت، فضـلًا عن أنها تضـمن ثبـات التقيم وعدالتهـ نظـرًا لموضوعية التصحيح.

\section{سلبيات الاختبار باستخدام التابلت:}

وعلى الرغم من مميزات الاختبار الإلكتروني إلا أن الأجهزة التي يجرى عليها الاختبار تكون

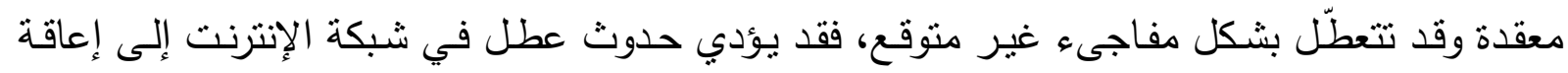

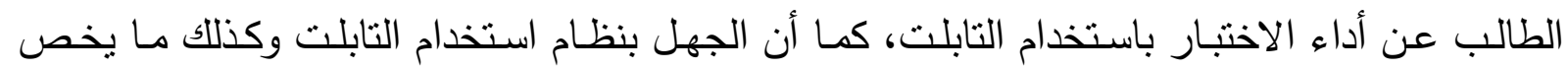

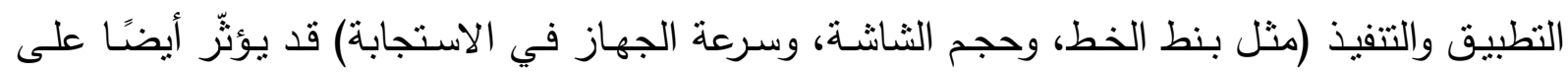
درجات الطلبة وقد ينسبب في قلق الطلبة قبل أو أثناء تتاول الاختبار (Kyllonen, 2009, p. 151). كما أن معظم الاختبارات الإكترونية تقوم على أنماط من الأسئلة مثل الاختيار من متعدد

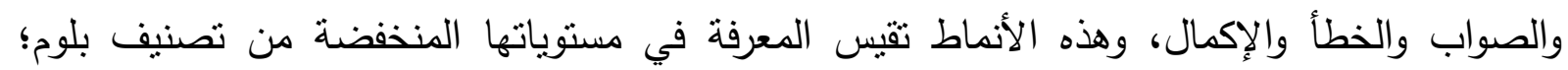

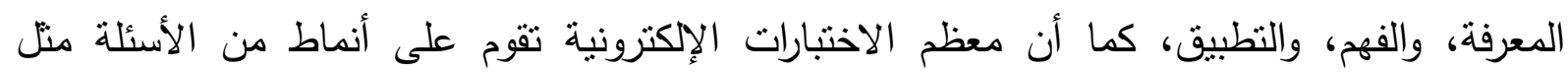

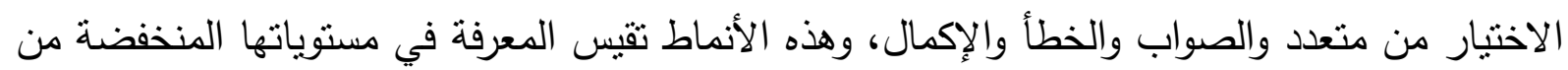
تصنيف بلوم؛ المعرفة، والفهم، والنطبيق (Hettiarachchi, Huertas, \& Mor, 2013, 12). فقد بشعر الطلبة بالقلق عندما يتعطّل جهاز التابلت قبل أو أثثاء أداء الاختبار ، أو عندما يحدث

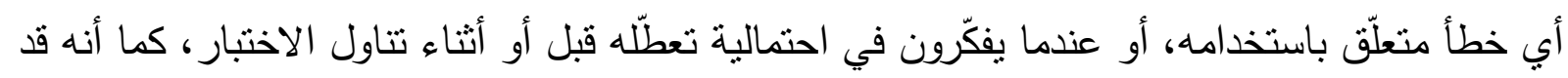

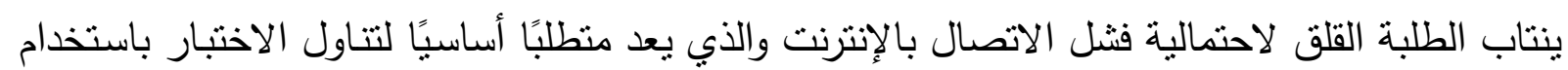

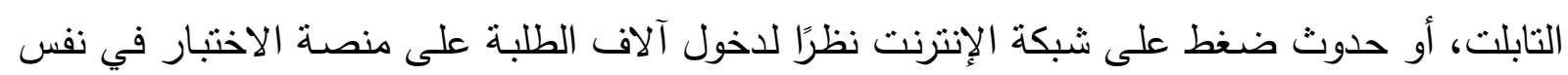

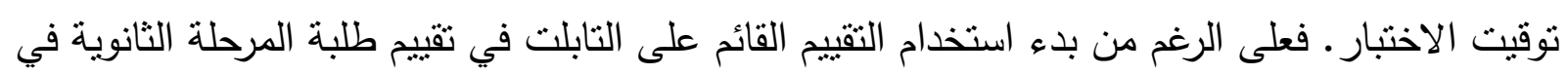

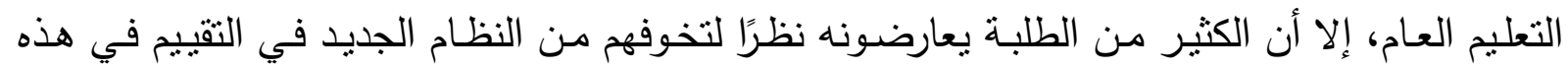
المرحلة الدراسية الحرجة؛ وهي المرحلة الثانوية العامة. ماهية قلق الاختبار باستخدام التابلت:

قامت العديد من البحوث بدراسة مصطلح قلق الاختبار حيث تستخدم الاستخدام الاختبارات بشكل مستمر

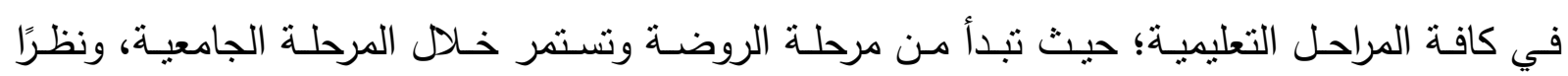

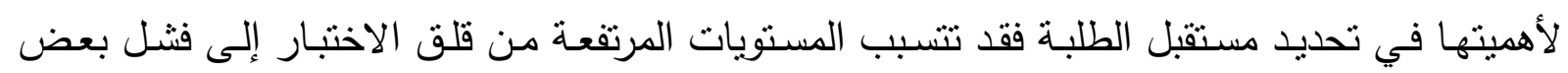
الطلبة أكاديميًا (Javanbakht \& Hadian, 2014, p. 776). 
فقلق الاختبار قد يؤثر سلبًا على إنجاز الطلبـة الأكاديمي وأيضًا على صحتهم النفسية والجسمية، وقد يتسبب ضعف مهارات الطلبة الدراسية الأكاديمية، وعدم استذكارهم، وعدم استعدادهم الكافي للاختبار في معاناتهم من قلق الاختبار، ويعد قلق الاختبار مشكلة كبيرة تؤرق العديد من الطلبة، وقد تعوق أداءهم الفعال في مختلف المواقف التعليمية بوجهه عام والمواقف الاختباريـة بوجه خاص، ويرتبط قلق الاختبار بالخوف من التقييم السلبي ونقص توظيف مهارات الدراسـة الفعالة، ومن ثم فالطلبة مرتفعو قلق الاختبار يواجهون صعوبات أكبر في التعلم ويتعرّضون للتداخل المعرفي وتتنت الانتباه أثناء تتاول الاختبارات

.(Damer \& Melendres, 2011, p. 164)

وتعرّف خريبه (0 1 • Y، ص T 1) قلق الاختبار الإلكتروني بأنه توتز واضطراب موقفي ينتاب الطالب

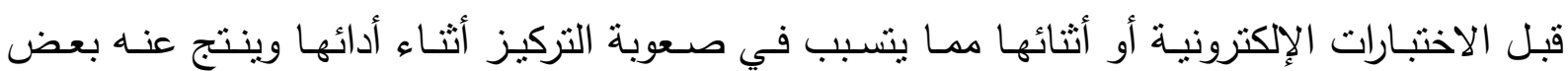
الأعراض الفسيولوجية التي تتتهي بانتهاء الاختبار.

أما Carr (2016, p. 3 فيرى أن قلق الاختبار يشير إلى تفكير الطلبة في الفنثل في الاختبار، وأيضًا إلى نتنتهم وعدم التتظيم الذي يعانون منه قبل وأثناء الاختبارات، مصحوبًا بأعراض فسيولوجية لاإرادية (مثل، التعرق، والإسهال، والارتجاف) وهي أعراض مزعجة تسنتيرها الاختبارات، ومن ثم يشعر قلقو الاختبار بالتوتز والقلق والانزعاج قبل وأثناء تتاول الاختبارات.

\section{مستويات قلق الاختبار باستخدام التابلت:}

ويوجز Fulton (2016, p. 5) مستويات قلق الاختبار وخصائص كل مستوى في وجود ثلاثة مستويات؛ منخفض، ومثالي، ومرتفع؛ ويتّم أصحاب المستوى المنخفض من قلق الاختبار بقلة التركيز في الإعداد للاختبـار ، وتخصسيص وقت ضـيق لمراجعـة المحتوى، والنظـر لنتائج الاختبـار على أنها غير مهــة؛ ومستوى مثالي من قلق الاختبار ، ويتميز أصحابه بالاستعداد المناسب للاختبار ، ومراجعة محتوى المادة التعليمية بشكل جيد، والنظر لنتائج الاختبار على أنها مهمة؛ ومستوى مرتفع من قلق الاختبار ، ويتصف

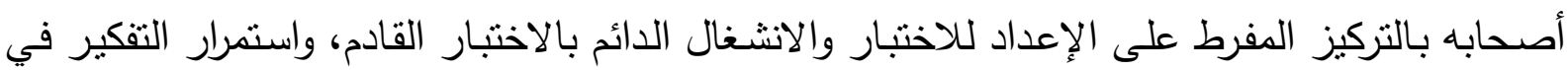
مدى صحة أو خطأ إجابـاتهم عن الاختبـارات التي أدوهـا بالفعل، وقضـاء وقت كبير في الاستذكار (بتعجّل)، والنظر لنتائج الاختبار على أنها بالغة الأهمية.

ومن ثم توجد عدة أسباب لقلق الاختبار فقد يرجع قلق الاختبار باستخدام التابلت إلى أسباب معرفية أو دافعية أو انفعالية أو نفسية أو أسرية أو بيئية أو مدرسية أو أسباب تتعلق بصعوبة الاختبار . وهناك ثلاثة مستويات من قلق الاختبار (منخفض، منوسط، مرتفع) وأفضلهم هو المستوى المتوسط من القلق حيث يكون هو المستوى المثالي. 


\section{نماذج قتّ الاختبار باستخدام التابلت:}

ويوجد أكثر من نموذج لقق الاختبار؛ فهناك نموذج النقص، ونموذج التذاخل، والنموذج التفاعلي. وتتمايز تلك النماذج؛ حيث يفترض نموذج النقص أن قلق الاختبار لا يعد سببًا مباشرًا في انخفاض التحصيل الدراسي، وإنما يرجع قلق الاختبار إلى معاناة الطلبة ذوي القدرات العقلية المنخفضة من قلق الاختبار نظرًا لقلة استعدادهم للاختبار، وافتقارهم لاستراتيجيات ناجحة لتتاول الاختبار، وممارستهم لعادات استذكار غير فعالة، ونقص وعيهم باحتمالية نجاحهم في الاختبار ، أما نموذج التداخل فيرى أن قلق الاختبار ينتج عن تعرض الطلبة لتذاخل معرفي يؤدي إلى انخفاض التحصيل الدراسي حيث نتتاب الطالب أثتاء تتاول الاختبار أفكار غير مرتبطة بالمهام المطلوب أدائها في الاختبار مما يؤدي إلى لئ إخفاقه؛ أي يحدث القلق بسبب نقص التحكم الانتباهي لاى الطالب، وبالنسبة للنموذج التفاعلي فينتج قلق الاختبار عن الضغط الذي يعاني منه الطالب عندما يدرك عدم كفاءة قدراته في مواجهة الموقف الاختباري الضاغط، ويركز هذا النموذج على التفاعل بين البيئة وسمات شخصية الطالب، ويعد هذا قلق حالة حيث يعتمد على استجابة الطالب للتهديدات المدركة الخاصة بالاختبار مثل إدراك الطالب لصعوبة الاختبار ، أو استخدام درجات الاختبار كعامل حاسم هام في اتخاذ القرارات الأكاديمية الخاصة بالطالب،

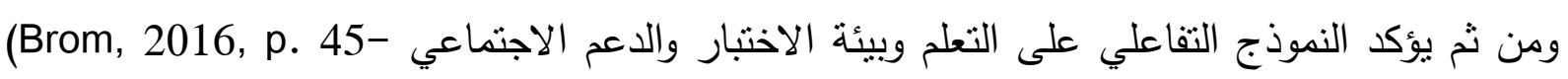

\section{نظريات قلق الاختبـار باستخدام التابلت :}

وهناك العديد من النظريات التي حاولت تفسير قلق الاختبار؛ منل النظرية السلوكية المعرفية ونظرية القلق كحالة / كسمة، ونظرية معالجة المعلومات. والنظرية السلوكية المعرفية هي خليط ناتج عن دمج مبادئ النظرية السلوكية والنظرية المعرفية معًا، وتفترض أن الاختبارات تتشّط المخطّطات المعرفية طويلة الأجل والتي تفترض الفشل المؤكد، فعندما يدرك الطالب مرتفع قلق الاختبار أن موقف الاختبار يمثل تهديدًا له لا يؤدي بشكل جيد مما يسهم في تدعيم الأفكار غير التكيفية التي ينتج عنها إزعاجًا وجدانيًا ومشكلات سلوكية، ونظرية القلق كحالة / كسمة نرى أن مرتفعي القلق كسمة عرضة للمعاناة من أعراض فئل القلق حيث يقيّمون الموقف الاختباري على أنه منشّط للخوف من الفنشل لديهم، وتفترض هذه النظرية أن مرتفعي قلق الاختبار كسمة قد يكونوا أعلى في قلق الاختبار كحالة، ويشير قلق الاختبار كحالة إلى القلق في موقف تقييمي محدد، بينما يشير قلق الاختبار كسمة إلى القلق في جميع المواقف التقبيمية، وتقارن نظرية معالجة المعلومات التفكير الإنساني بالوظائف المتعددة للحاسوب، ولها ثلاتة مكونات:

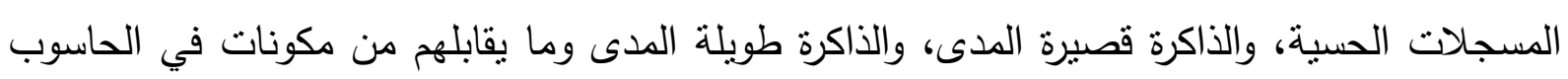
هي المسجلات، ووحدة المعالجة المركزية، ووحدة التخزين الصلبة، وتفترض هذه النظرية أن قلقي 
الاختبار يواجهون صعوبة في معالجة المعلومات أثناء الاختبارات نتيجة فثلهم في الترميز والاسترجاع مما يؤدي إلى عجزهم في أداء الاختبار (7-7) 2016, pp. 3).

\section{مكونات قلق الاختبار باستخدام التابلت:}

يعد التقييم باستخدام التابلت أحدث أنواع التقييم في المرحلة الثانوية بمصر في الوقت الحالي، وقد ينتج عنه قلق الاختبار والذي يعد توتز موقفي يحدث قبل أو أثناء تتاول الاختبار باستخدام التابلت مما يتسبب في إعاقة تركيز الطالب وينتج عنه أعراض فسيولوجية. ولقلق الاختبار باستخدام التابلت عدة مكونات سوف يتم تتاولها كما يلي.

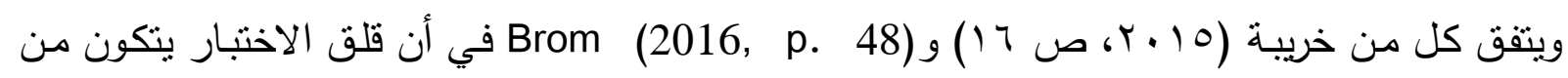
مكونين هما: المكوّن المعرفي، والذي يتمثل في الانزعاج وانشغال الطالب بالتفكير في تبعات فنشله في الاختبـارات الإلكترونيـة مثنل فقدان مكانته أو التقدير الذي يحظى بـه في المجتمـع المحيط، والمكوّن الانفعـالي، والذي يتمثن في شـعور الطالب بالضـيق والتوتر والخوف مـن الاختبـارات الإلكترونيـة ومـا يصاحب ذلك من تغيرات فسيولوجية مزعجة.

ويرى Carr (2016, p. 4 أن قلق الاختبار هو مفهوم متعدد الأبعاد؛ حيث يتكون من مكونات انفعالية، وسـوكية، وفسـيولوجية، فقد تتضــن أعـراض قلق الاختبـار وجـود تـوتر، وتجنـب، وأفكـار لاعقلانيـة،

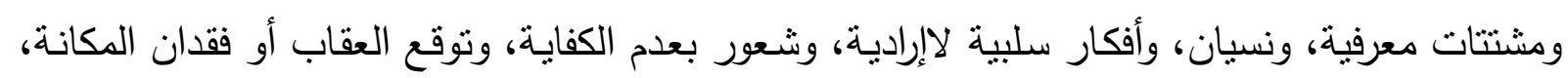
وأعراض فسيولوجية آلية منت التعرق، وخفقان القلب، والشعور بعدم الراحة. أسباب قلق الاختبار باستخدام التابلت:

وهناك عدة أسباب لقلق الاختبار؛ فقد ينتج قلق الاختبار عن نقص المعرفة لدى الطالب بالموضوعات الدراسـية، أو وجـود مشـكلات لديـه في الاسـتذكار أو تتظيم المعلومـات أو مراجعتهـا قبـل الاختبـار أو استدعائها أثنائه، أو ارتبـاط الاختبار بخبرات فثنل في حياة الطالب، أو قصور الطالب في الاستعداد للاختبار ، أو وجود قصور عند الطالب في مهارات ثتاول الاختبار ، أو نقص ثقة الطالب بنفسه، أو وجود اتجاهات سالبة لدى الطلبة والمعلمين والوالدين نحو الاختبارات، أو صعوبة الاختبارات، أو الثعور بأن الأن مستقبل الطالب من حيث نجاحه أو فثنله يتوقف عليها، أو الضغوط البيئية على الطالب لتحقيق مستوى

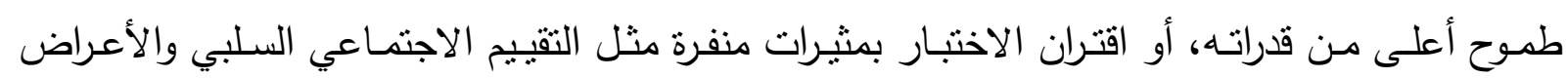
الفسيولوجية المصاحبة المزعجة، أو الخوف من المستقبل المجهول نتيجة الرسوب أو عدم الحصول على تقدير مرتفع، أو الخوف من صعوبة أسئلة الاختبار ونوعيتها، أو الخوف من نسيان أو تداخل المعلومات

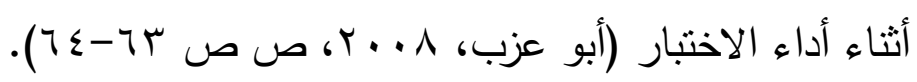


ويحدث قلق الاختبار عندما يشعر الطالب بالخوف والضيق والتوتر وعدم الراحة أثناء أو قبل أو بعد أداء اختبار معين، وهذا الثعور قد يكون له تأثيرات ميسّرة أو معوّقة على عملية التعلم، فالقلق الزائد يؤثز سلبًا على الآداء حيث يتداخل مع قدرة بعض الطلبة على تذكر ما درسوه، وقد وجد بعض الباحثين أن هناك علاقة ارتباطية قوية دالة إحصائيًا بين مستوى قلق الاختبار لدى الطلبة وأدائهم في الاختبار ، بينما وجد

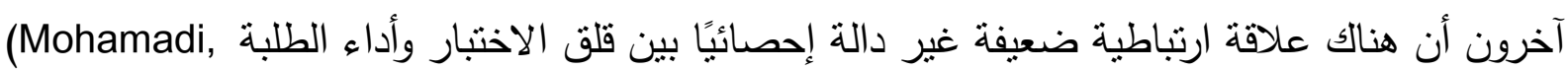
.Alishahi \& Soleimani, 2014, p. 1157)

\section{تبعات قلق الاختبار باستخدام التابلت:}

قد يتسبب قلق الاختبار في سلوكيات سلبية منتوعة، منثل البكاء، أو القيء، وانفعالات مزعجة، مثنل التوتر، والخوف، والشعور بالضغوط، مما قد يدفع بعض الطلبة للتسرع في إجابة الاختبار، كما قد يرفض بعض الطلبة تكملة جزء من أجزاء الاختبار ، والبعض الآخر قد ينسحب بعد إكمال القليل من الأسئلة، كذلك فقد يتبع الكثير من الطلبة السلوك التجنبي مثن الحملقة في الجدران أو السقف، أو اللعب بالقلم، ويسلك الطلبة هذه السلوكيات للهروب من الخبرة غير السارة المسببة للقلق-خبرة أداء الاختبار باستخدام التابلت مما يتسبب في تشتتيت الطلبة عن مهمة الاختبار وإعاقة أدائهم (Fulton, 2016, p. 6). وبشعر الطلبة الذين يعانون من قلق الاختبار بالتوتر والأرق وفقدان الثهية وتسلط بعض الأفكار الوسواسية وكثرة التفكير في الاختبارات والانشغال قبل وأثناء الاختبار في نتيجته، وتسارع خفقان القلب مع جفاف الحلق والثفتين وسرعة التتفس وتصبب العرق، وألم البطن والغتيان، والثعور بالضيق الثديد قبل وأثناء تأدية الاختبار، واضطراب العمليات العقلية كالانتباه والتركيز والتفكير واستدعاء المعلومات أثناء أداء الاختبار حيث يشعر فيه الطالب بأن عقله فارغ من المعلومات المتعلقة بالاختبار ، وأنه نسي ماء ذاكره بمجرد الاطلاع على ورقة أسئلة الاختبار، ووجود تداخل معرفي يتمثل في أفكار سلبية عن الاختبارات ونقص إمكانية المعالجة المعرفية للمعلومات، وهذه الأعراض والسلوكيات الفسيولوجية

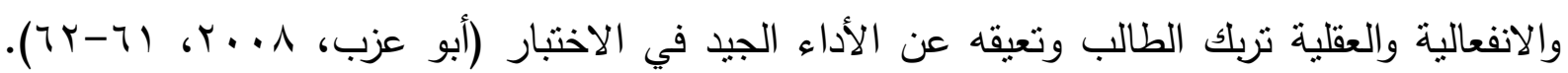
نظري

وينشغل مرتفعو قلق الاختبار بأنفسهم وعدم كفايتهم والانطباعات السلبية التي قد يتركونها لدى الآخرين، مما قد يتعارض مع أدائهم للاختبار (Carr, 2016, p. 9). البحوث والدراسات السابقة:

هدف بحث الرفاعي والفضلي (10 ـ ب) إلى التعرف على الفروق في قلق الاختبار تبعًا لمتغيرات النوع والتخصص والمستوى التحصيلي لاى طلبة كلية التربية الأساسية بدولة الكوبت. وتكونت عينة البحث من 


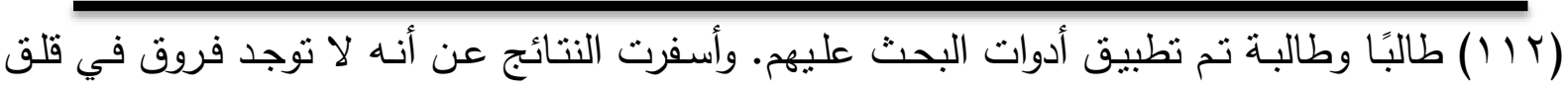
الاختبار ترجع للنوع.

وحاول بحث نصر (10 ب ب) الكثف عن مستوى قلق اختبار الرياضيات لدى طلبة المرحلة الأساسية

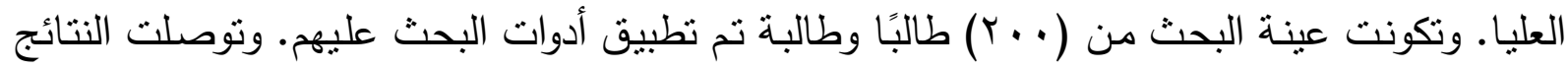
إلى وجود مستوى متوسط إلى مرتفع من قلق الاختبار لدى طلبة المرحلة الأساسية العليا. وقام بحث (2015) Crisan \& Copaci Cبتحليل العلاقات المحتملـة بين قلق الاختبار والأداء

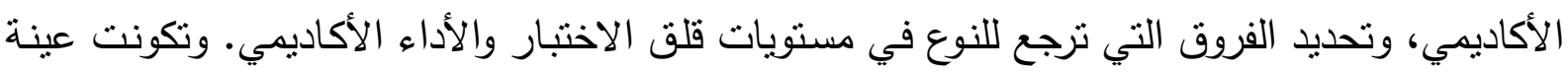

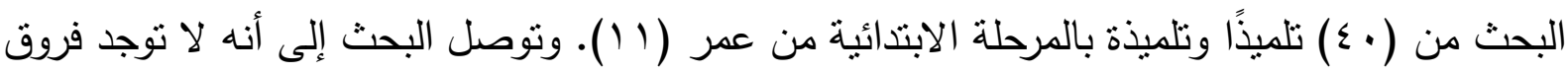

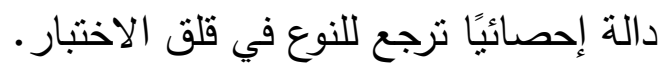

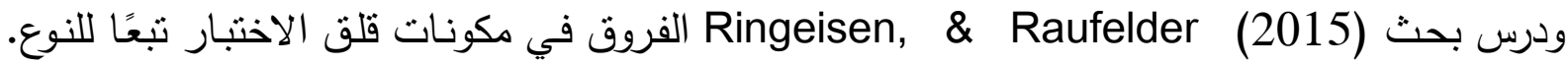

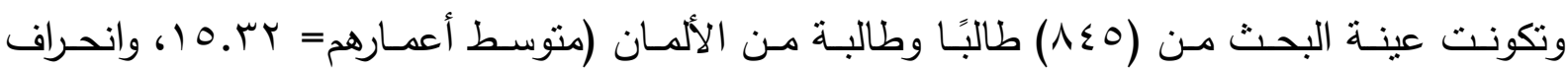

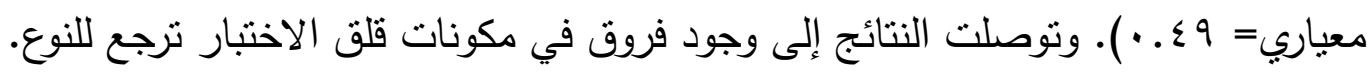
وهدف بحث الرواشدة (7 ( • إ) إلى التعرف على مستوى قلق الاختبار والفروق في قلق الاختبار تبعًا

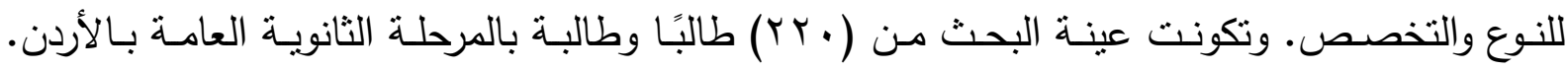

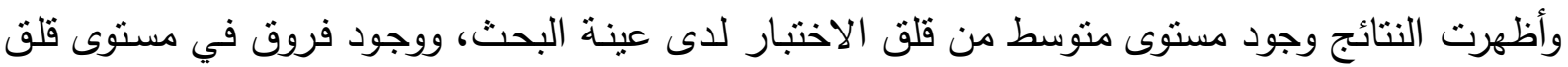

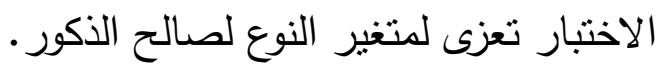

وحاول بحث الضريبي (T 1 ب) التعرف على طبيعة العلاقة بين دافعية الإنجاز وقلق الاختبار ـ وتكونت

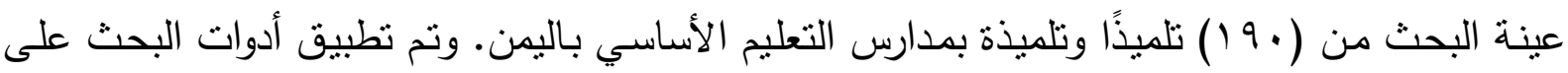

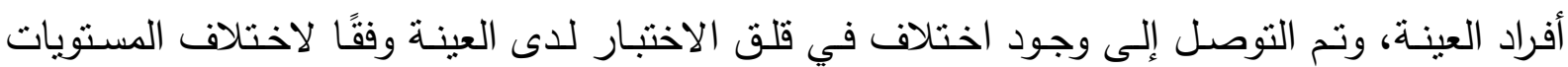
الدراسية لصالح الصف السادة؛؛ أي لصالح الصف الأقل عمرًا. وقام بحث المصاروة (7 ( ب ب) بالتعرف على مستوى قلق الاختبار واختلافه تبعًا للنوع لدى طلبة الجامعة.

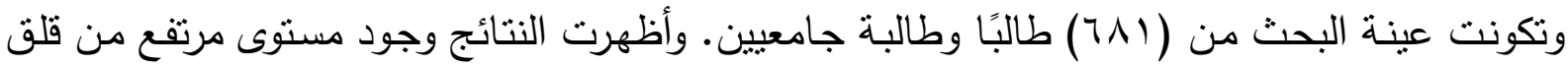
الاختبار لاى عينة البحث، ووجود فروق في مستوى قلق الاختبار تعزى للنوع لصالح الإناث. ودرس بحث (2016) Sung, Chao, \& Tseng العلاقة بين قلق الاختبار والإنجاز الأكاديمي لدى

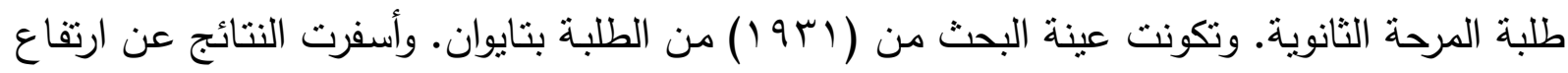
مستوى قلق الاختبار لاى الإناث مقارنة بالذكور • 


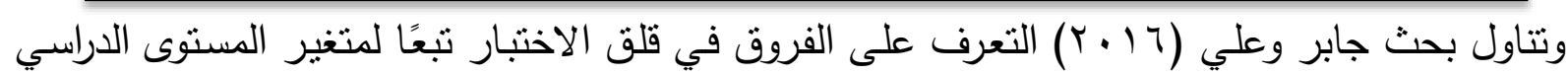

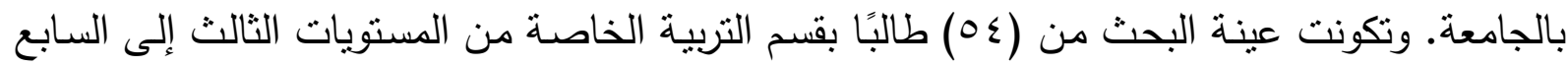

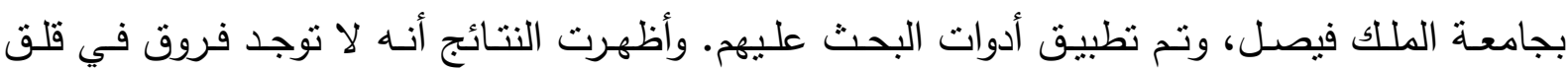
الاختبار نرجع إلى المستويات الدراسية بالجامعة.

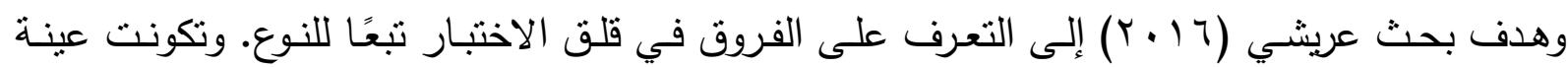

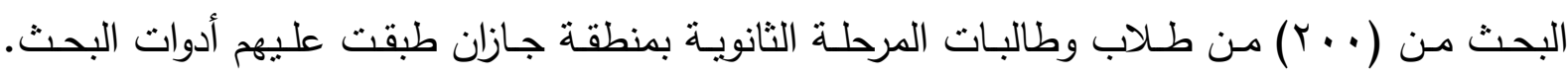

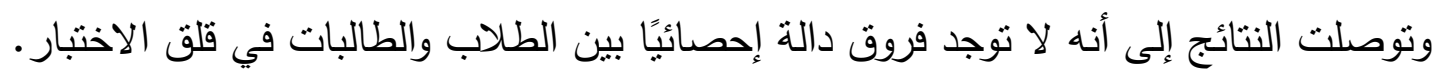

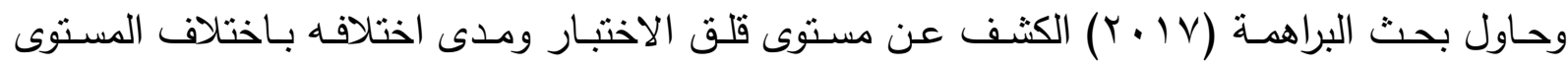

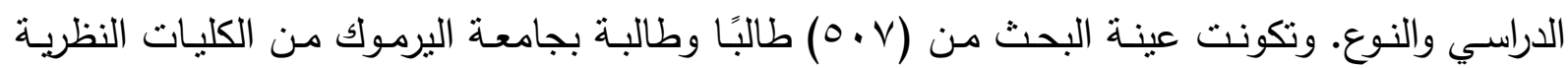

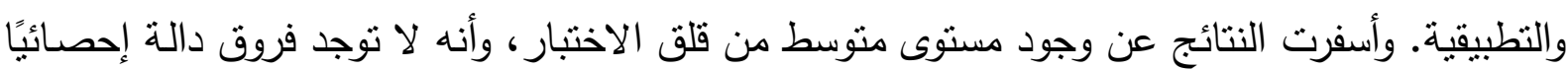
في مستوى قلق الاختبار تعزى لمتغيرات المستوى الدراسي والنوع.

وهدف بحث حسن (Y V P r) إلى التعرف على علاقة قلق الاختبار ببعض المتغيرات النفسية لدى طلبة

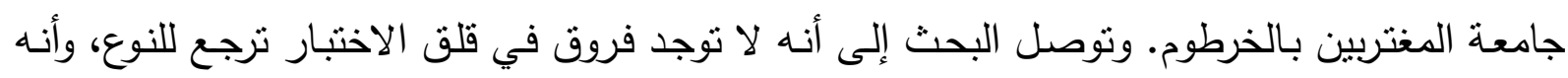

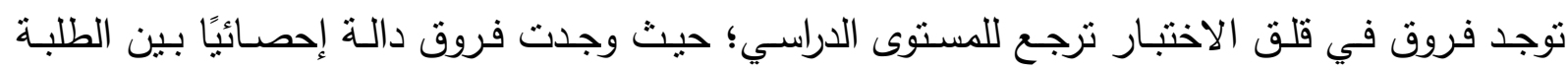
القدامى والجدد لصالح الطلبة الجدد. وحاول بحث أبو الثيخ (11) الكثف عن أثر قلق الاختبارات الإلكثرونية على أداء طالبات كلية

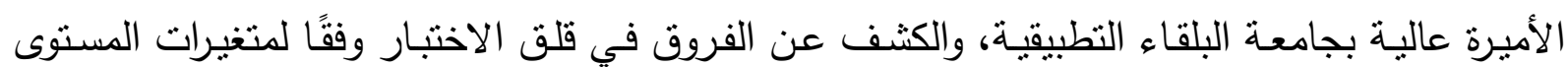

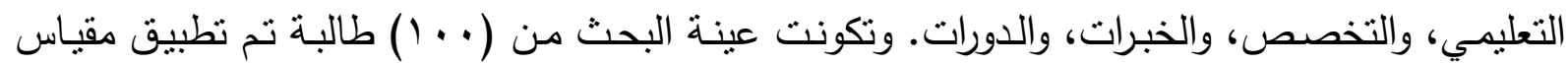

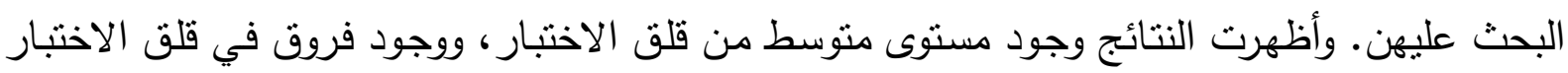
وفقًا لمتغيرات المستوى التعليمي والتخصص والخبرات والدورات.

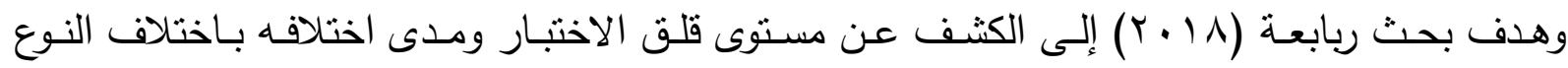

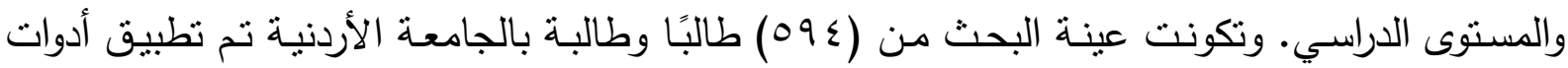

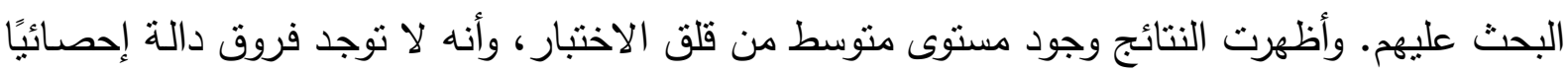
في قلق الاختبار تعزى لمتغيرات النوع والمستوى الدراسي.

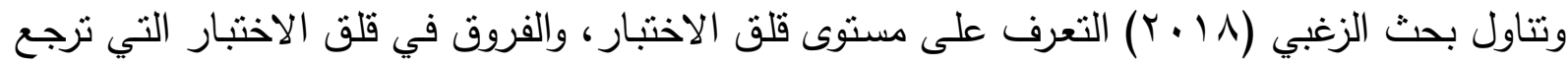

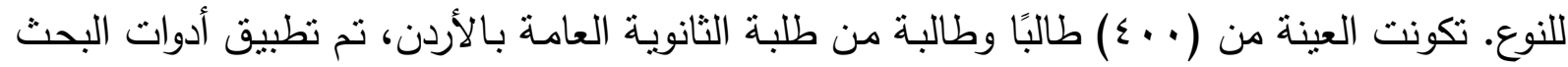


عليهم. وأظهرت النتائج وجود مستوى مرتفع من قلق الاختبار لدى أفراد العينة، ووجود فروق في مستوى قلق الاختبار تعزى لمتغير النوع لصالح الإناث.

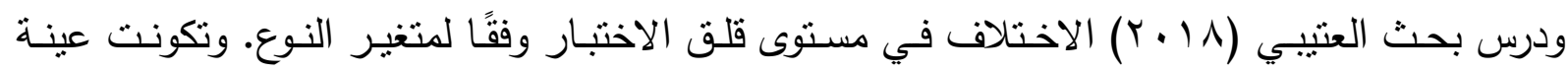
البحث من (T (Y) من طلبة كلية التربية؛ (101 (1) طالبًا و (70) طالبـة تم تطبيق أدوات البحث عليهم. وأسفرت النتائج عن وجود فروق دالة في مستوى قلق الاختبار تبعًا لمتغير النوع لصالح الإناث.

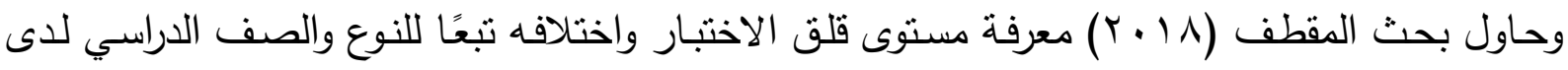

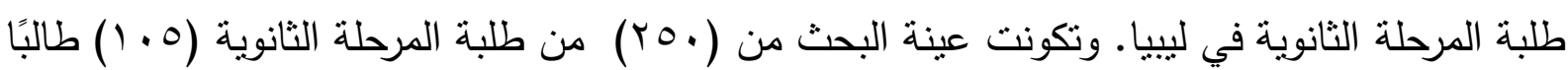
و (0ء () طالبة بالقسمين العلمي والأدبي بالمدارس الثانوية بليبيا. وأظهرت النتائج وجود مستوى متوسط

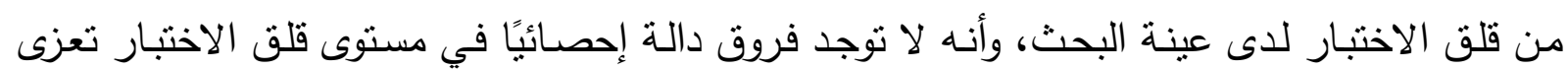
لمتغيرات النوع والصف الدراسي.

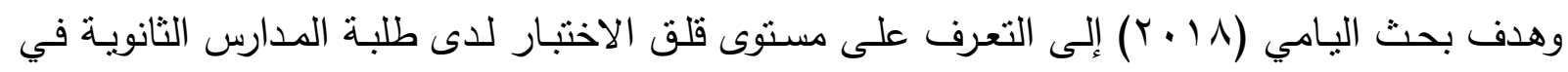
نجران بالسعودية. وتكونت عينة البحث من ( . . ؟) طالبًا وطالبة بالمرحلة الثانوية تم تطبيق مقياس قلق الاختبار عليهم. وكثفت النتائج عن وجود مستوى منوسط من قلق الاختبار لدى عينة البحث، ووجود فروق دالة إحصائيًا في قلق الاختبار تبعًا لمتغير الصف الدراسي لصالح طلبة الصف الثالثة الثانوي؛ أي لصـالح المستوى الدراسـي الأعلى، ووجود فروق دالة إحصـائًا في قلق الاختبار تبعًا لمتغير النوع لصالح الإناث.

وهدف بحث (2018) Ahmad, Hussain, \& Khan إلى تحديد مستوى قلق الاختبار لدى طلبة الجامعة، والتعرف على العلاقة بين قلق الاختبار لديهم وتحصيلهم الأكاديمي، وكذلك تحديد العلاقة بين

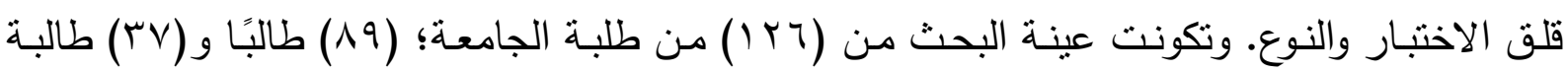

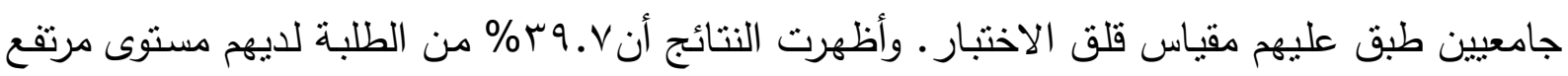

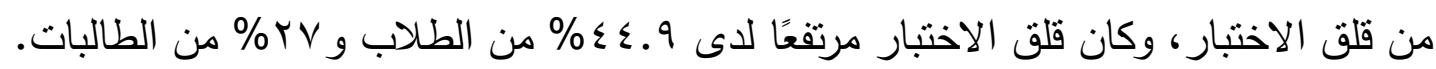
وفحص بحث (2018) Dalaman \& Medikoglu مستوى قلق الاختبار لدى التلاميذ ممن تمتد أعمارهم من ( • (-M () عامًا ومدى تأثر قلق الاختبـار ببعض المتغيرات. وتكونت عينة البحث مـن ( T Y I ) مـن تلاميذ الفـرق الرابعـة والخامسـة والسادسـة الابتتائيـة. توصـل البحث إلى وجـود ارتبـاط دال إحصائًا بين العمر وقلق الاختبار ، وأن قلق الاختبار مرتفع لدى الطالبات أكثر من الطلاب. وهدف بحث (2018) Sari, Bilek, \& Celik إلى تحديد مستوى قلق الاختبار لدى طلبة المرحلة الثانويـة بتركيا. تكونت عينـة البحث من (ع VY) طالبًا وطالبة من المتقدمين للالتحاق باختبـارات قبول 
الجامعة، وتم تطبيق أدوات البحث عليهم إلكترونيًا. وتوصلت النتائج إلى أنه يوجد تأثير للنوع على قلق الاختبار ؛ حيث أظهرت الطالبات مستوى أعلى من قلق الاختبار مقارنة بالطلاب.

وحاول بحث Vaz, Pothiyil, George, Alex, Pothiyil, \& Kamath (2018) قياس قلق الاختبار

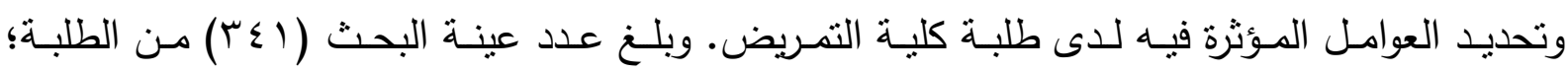

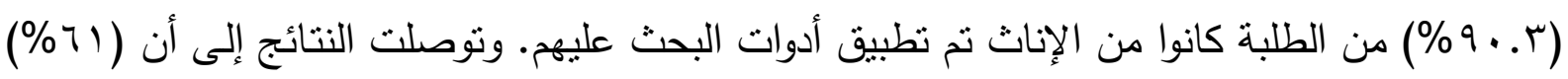
من العينة كان قلق الاختبار لديهم منخفضًا جدًا، و هب\% كان مستوى قلق الاختبار لديهم منخفضًا،

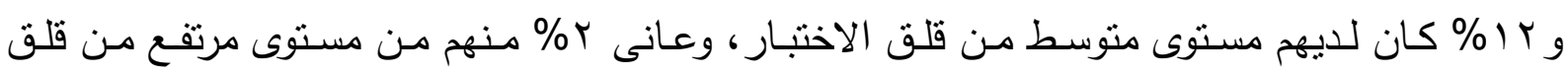

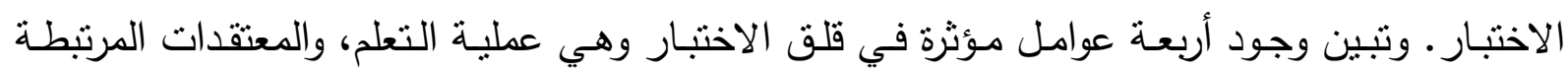
بالاختبار ، ونمط التعلم، والتوقعت المرتفعة المرتبطة بالمخرجات التعليمة. ودرس بحث المجمعي (9 1 ـ ( الفـروق في قلق الاختبـار تبعًا للصف الدراسـي لدى طـلاب الجامعـة بالسعودية. وتكونت عينة البحث من (0) ؟ طالبًا جامعيين. وتم تطبيق أدوات البحث على العينة، وتم التوصل إلى أنه لا توجد فروق في مستوى قلق الاختبار بين المستوى الدراسي للمبتدئين والمتقدمين. وهدف بحث الندابي (9 1 • r) إلى التعرف على استراتيجيات التظظيم الانفعالي وعلاقتها بقلق الاختبار لاى عينـة من طلبة جامعتي السلطان قابوس بسلطنة عمان وجامعة محمد الأول في المملكة المغربية.

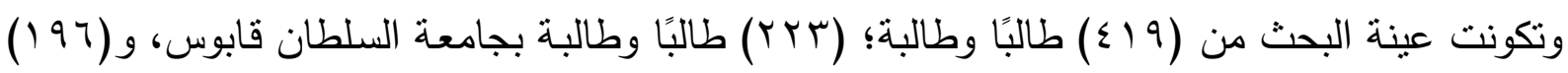

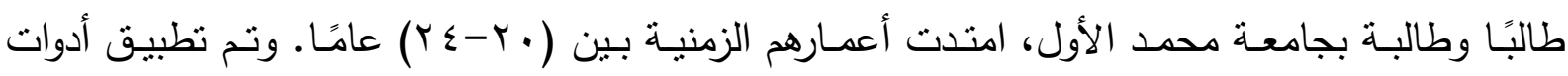
البحث على العينة وتوصلت النتائج إلى وجود فروق دالة إحصائيًا في مستوى قلق الاختبار بين طلبـة الجامعتين، كما تبين أن مستوى قلق الاختبار اختلف باختلاف النوع والبيئة الجغرافية لاى عينة البحث. وقام بحث (2019) بقياس قلق الاختبار لدى طلبة كلية طب الأسنان، وتحديد العوامل

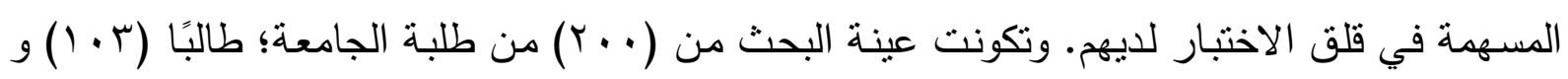
(9v) طالبة استجابوا إلكترونيًا لمقياس قلق الاختبار • وأظهرت النتائج أن معظم الطلبة كان لديهم مستوى مرتفع من قلق الاختبار، كما تبين ارتباط قلق الاختبار بالنوع، واتضـح أن العوامل الرئيسية المسببة لقلق الاختبار هي الأعباء الدراسية الكبيرة والخوف من الفشل أثناء الاختبار والاستخكار طوال ليلة الاختبار . وهدف بحث (2020) Stang, Altiere, Ives, \& Dubois إلى تحديد الاختلافات في قلق الاختبار والتي ترجع للنوع. وتم تطبيق أدوات البحث على عينة من طلبة الجامعة بأمريكا يدرسون مقرر مقدمة في

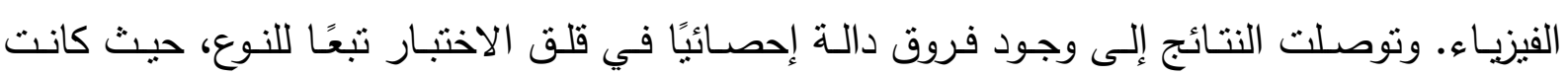
الطالبات أعلى في المكون الوجداني لقلق الاختبار . 


\section{التعقيب على البحوث والدراسات السابقة:}

هدفت بعض البحوث إلى معرفة مستوى قلق الاختبار مثنل بحث كل من نصر (10 ( ب)، والرواشدة

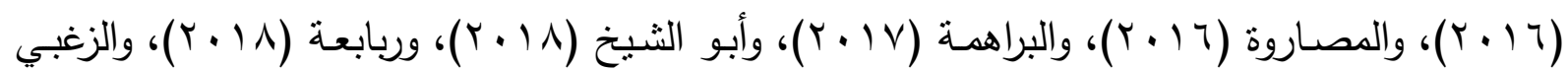

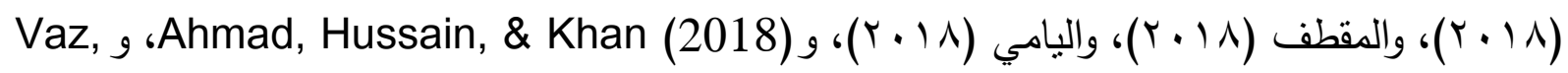
.Al-Sahman (2019) و (2018) وهدفت بعض البحوث إلى معرفة الفروق في قلق الاختبار تبعًا للنوع (ذكور - إناث) مثل بحث كل من Ringeisen, \& Raufelder (2015)، و الرواشدة (T) Crisan \& Copaci (2015)

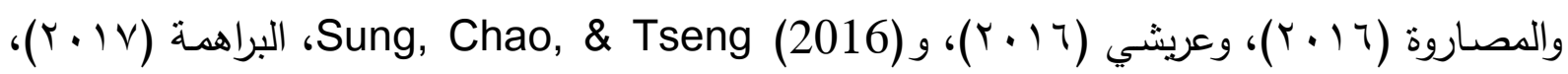

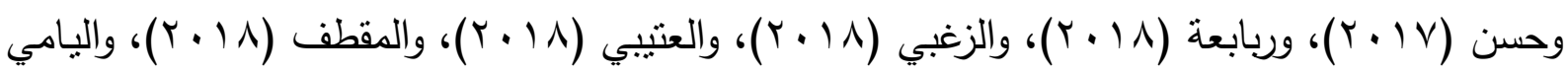

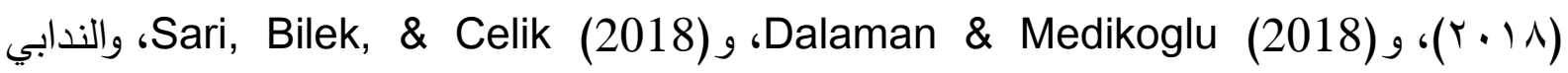

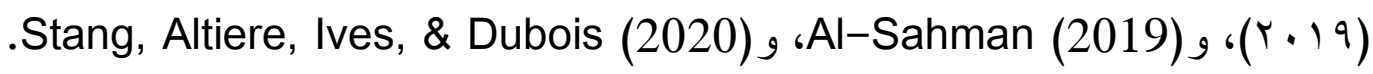
وقامت بعض البحوث بدراسـة الاختناف في قلق الاختبـار وفقًا للعمر أو للصف الدراسـي مثل بحث

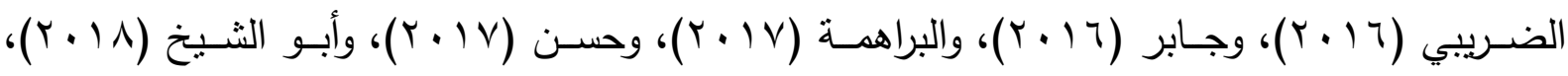

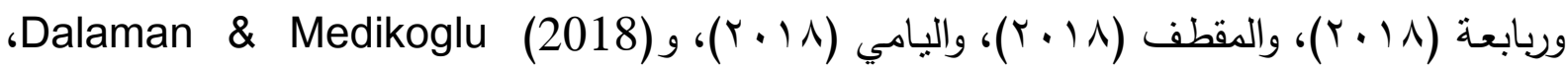

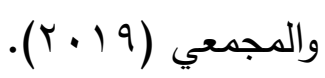

بينما هدف بحث واحد مما تم عرضه إلى معرفة الفروق في قلق الاختبار والتي ترجع إلى مكان الدراسـة

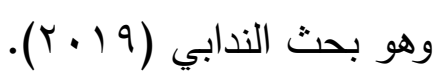

وسوف تقوم الباحثة بقياس مستوى قلق الاختبار باستخدام التابلت، والفروق في مستوى قلق الاختبار باستخدام التابلت والتي تعزى لكل من النوع والصف الدراسي ومكان المدرسة. وبالنسبة لعينات البحوث التي تم تتاولها فقد تباينت، حيث تم تطبيق بعض البحوث على تلاميذ المرحلة

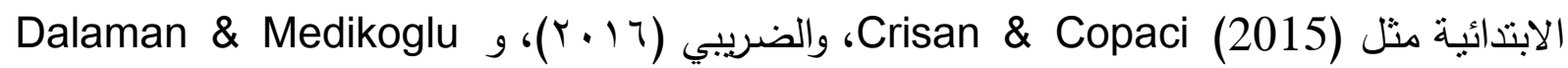

$$
\text { (2018)، وبحثًا واحدًا على طلبة المرحلة الإعدادية مثل بحث نصر (10 • ب). }
$$

Ringeisen, \& Raufelder بينما تم تطبيق العديد من البحوث على طلبة المرحلة الثانوية مثل بحث

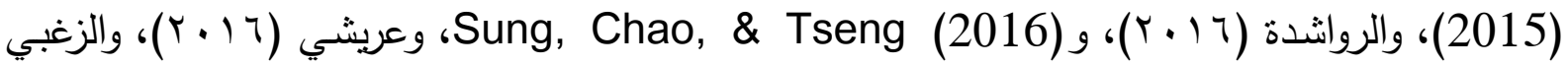

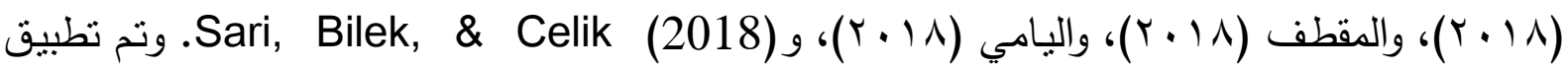

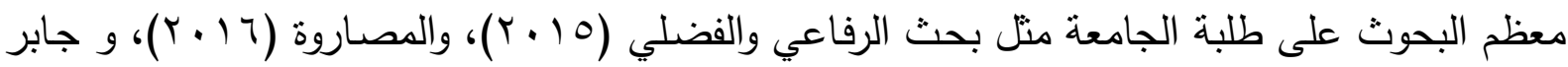

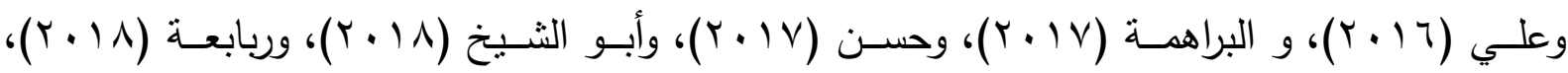




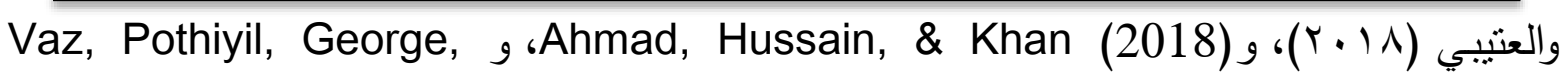
Al-Sahman والمجمعي (9lex, Pothiyil, \& Kamath (2018) .Stang, Altiere, Ives, \& Dubois (2020)، و (2019) وسوف تقوم الباحثة بالتطبيق على طلبة الصفين الأول والثناني الثانوي العام ممن يتتاولون الاختبار

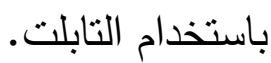

وفيما يخص النتائج التي توصلت إليها البحوث فيما يخص مستوى قلق الاختبار فقد تباينت؛ حيث كثفت نتائج بحث (2018) Kaz, Pothiyil, George, Alex, Pothiyil, \& Kamath أن معظم عينة

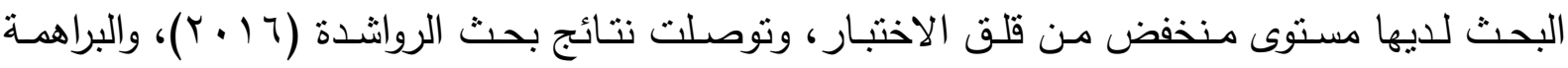

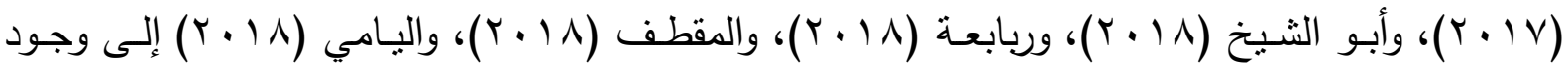

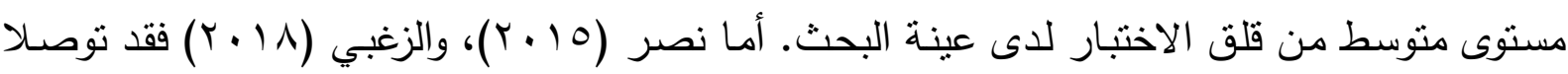

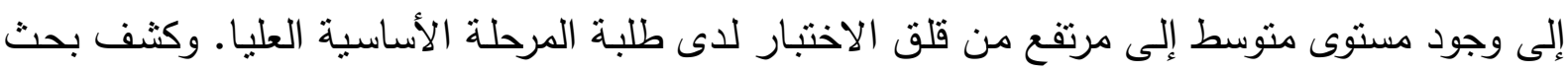
المصاروة (7 1 • ب)، و (2018) Ahmad, Hussain, \& Khan وجود مستوى مرتفع من قلق الاختبار . كما توصل (2019) Al-Sahman إلى أن معظم الطلبة كان لايهم مستوى مرتفع من قلق الاختبار، واتضح أن العوامل الرئيسية المسبية لقلق الاختبار هي الأعباء الدراسية الكبيرة والخوف من الفنشل أثناء الاختبار والاستذكار طوال ليلة الاختبار .

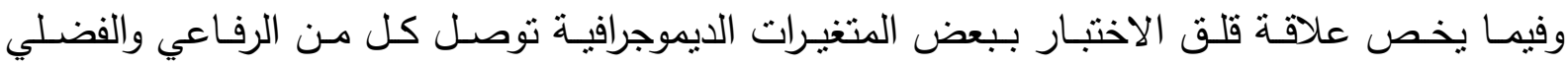

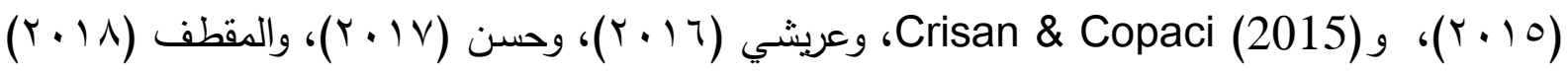

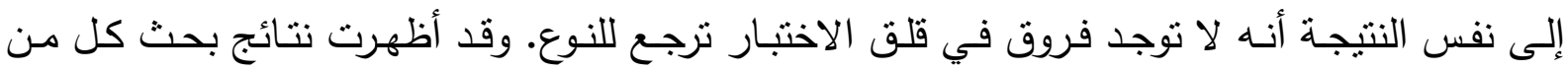

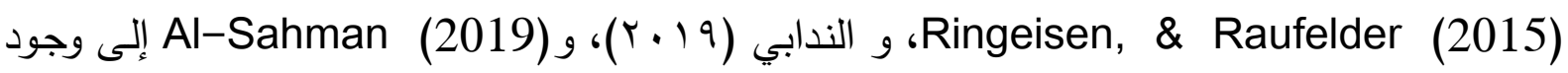

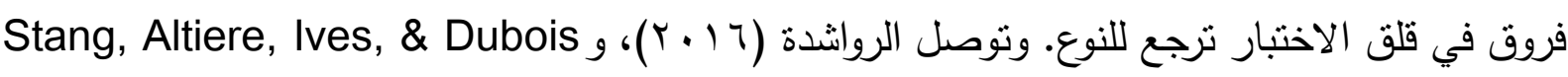

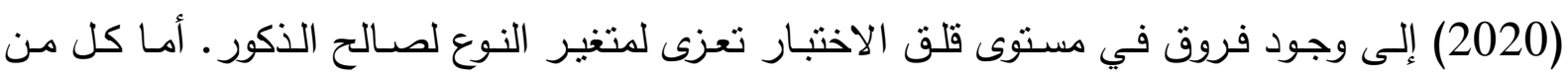

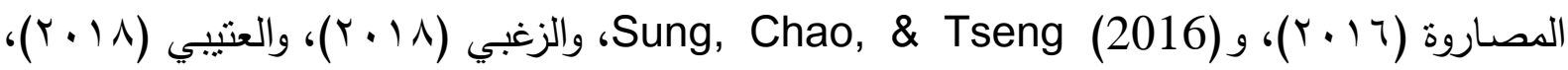

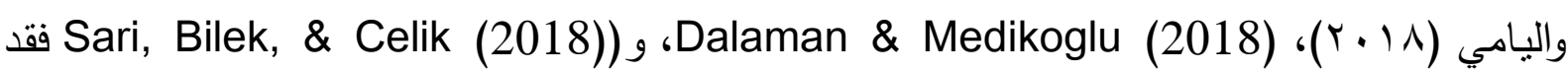
توصلوا إلى وجود فروق في مستوى قلق الاختبار تعزى للنوع لصالح الإناث.

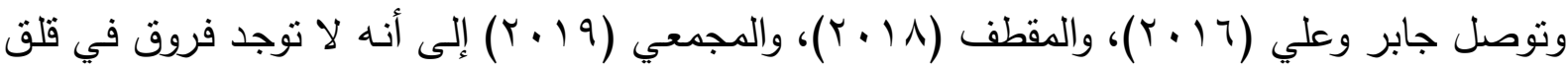

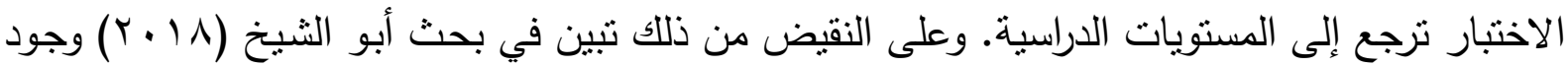

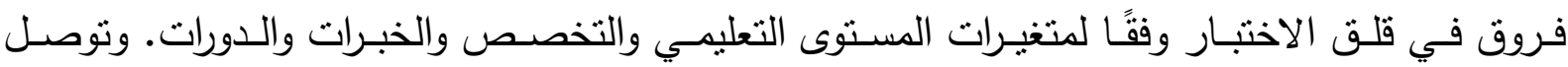
Dalaman \& Medikoglu (2018) 


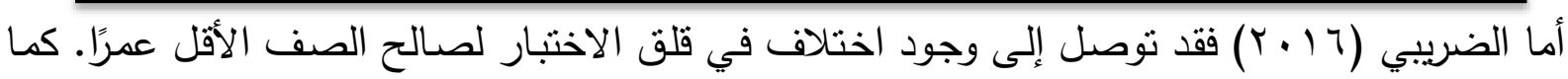

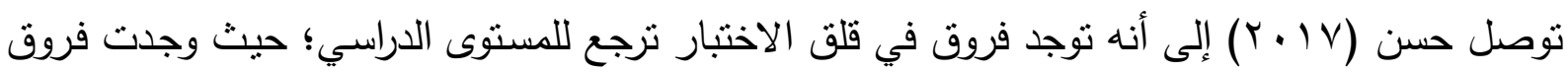

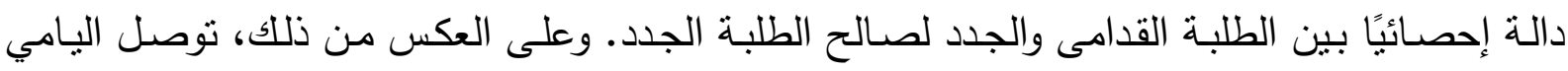

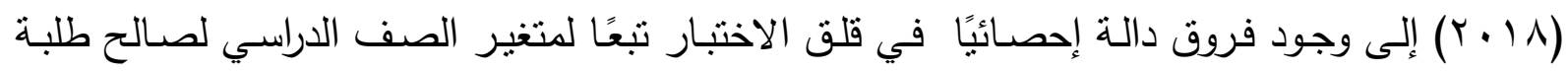
الصف الثالثة الثانوي؛ أي لصالح المستوى الدراسي الأعلى.

وكثفت نتائج بحث الندابي (9 ( ب) اختلاف مستوى قلق الاختبار باختلاف البيئة الجغرافية.

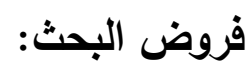

في ضوء نتائج ما تم عرضه من بحوث ودراسات سابقة يمكن صياغة فروض البحث الحالي كما يلي: 1- يوجد مستوى متوسط من قلق الاختبار باستخدام التابلت لدى طلبة المرحلة الثانوية العامة. ץ- لا يختلف مستوى قلق الاختبار باستخدام التابلت بـاختلاف نوع طلبة المرحلـة الثانويـة العامـة

$$
\text { (ذكور - إناث). }
$$

r- لا يختلف مستوى قلق الاختبار باستخدام التنابلت باختلاف الصف الدراسي لطلبة المرحلة الثانوية

$$
\text { العامة (الأول - الثاني). }
$$

ع - لا يختلف مستوى قلق الاختبار باستخدام التابلت باختلاف مكان مدرسة طلبة المرحلة الثانوية

$$
\text { العامة (الحضر - الريف). }
$$

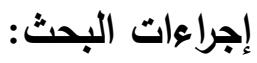

- منهج البحث: استخدم البحث الحالي المنهج الوصفي باعتباره المنهج الملائم للتعرف على مستوى قلق

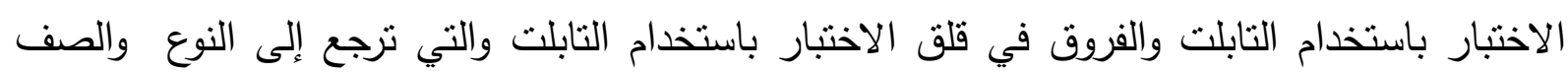

$$
\text { الدراسي ومكان المدرسة. }
$$

- مجتمع البحث وعيتته: تكوّن مجتمع البحث من جميع طلبة الصفين الأول والثاني الثانوي العام

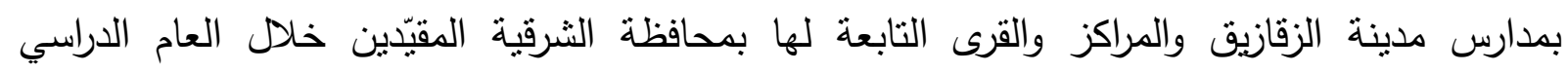

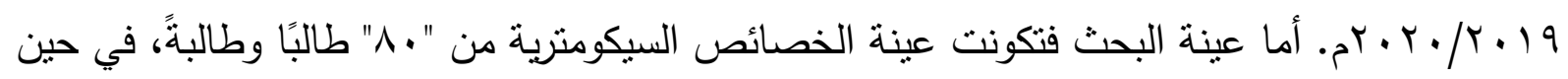

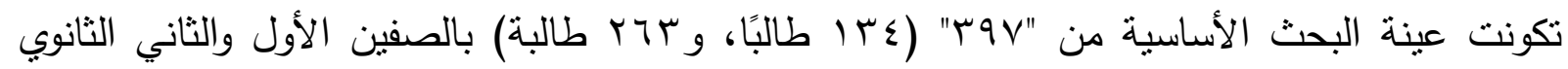

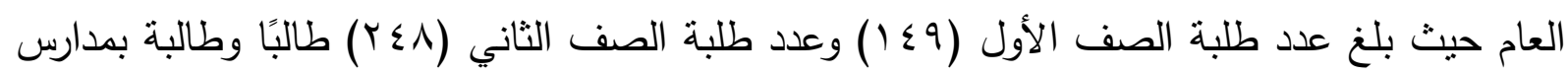
مدينة الزقازيق (مدارس الثهيد أحمد وحيد التجريبية للبنين، والثهيد شريف طلعت التجريبية للبنات،

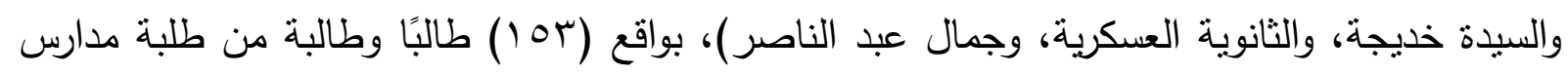
الزقازيق (الحضر)، ومدارس بمراكز الإبراهيمية وبلبيس وديرب نجم وأبو حماد وكفر صقر بمحافظة 
الثرقية بواقع (؟乏) من طلبة مدارس مراكز مدينة الزقازيق والقرى التابعة لها (الريف) بمنوسط أعمار

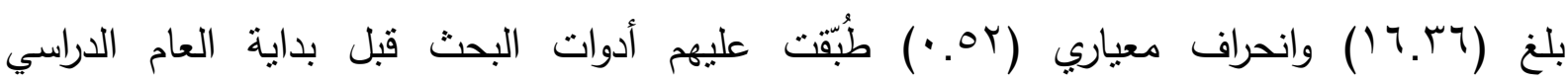
$\cdot r^{2} \cdot r Y / r \cdot r$.

مقياس "قلق الاختبار باستخدام التابلت" tablet-based test anxiety (إعداد الباحثة): لإعداد هذا المقياس قامت الباحثة بإجراء مسح لعدد من المقاييس العربية والأجنبية المنشورة فيما يخص

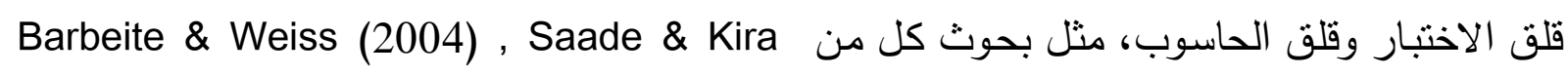

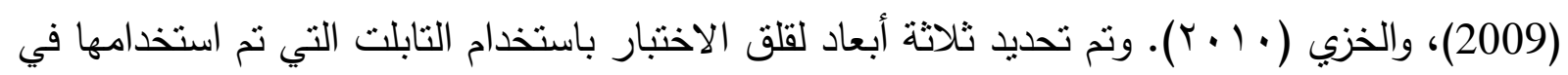

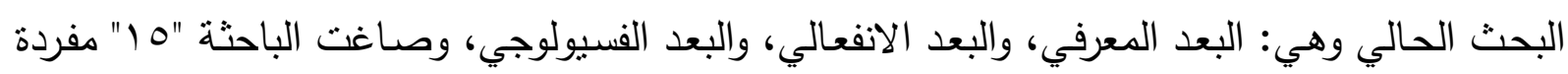

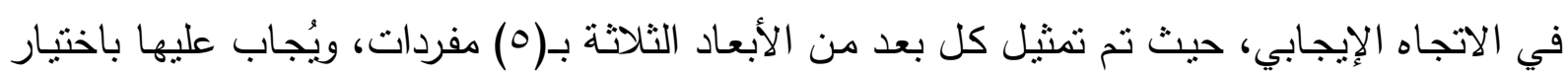

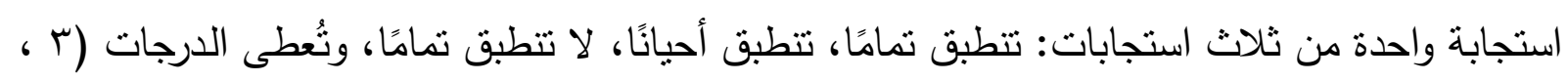
r ، ( ) على الترتيب، وللتأكد من صلاحية هذه المفردات قامت الباحثة بالإجراءات الآتية: - العرض على المحكمين: تم عرض المفردات والتعريفات الإجرائية لكل بعد من أبعاد قلق الاختبار

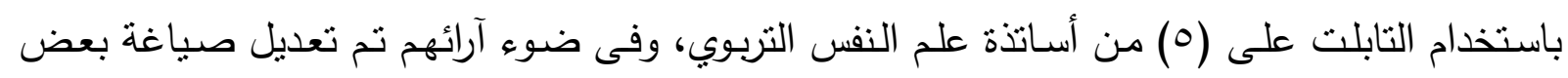

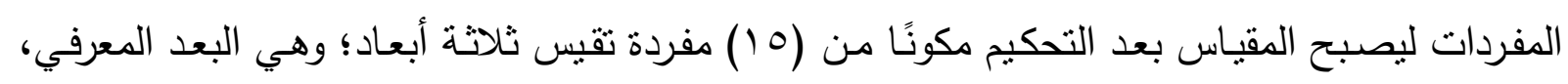

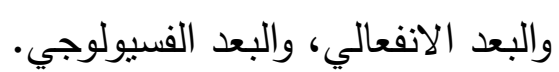
كما تم حساب بعض الخصائص السيكومترية لمقياس قلق الاختبار باستخدام التابلت للتحقق من الصدق

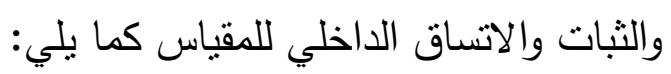
أولًا: صدق مقياس قلق الاختبار باستخدام التابلت:

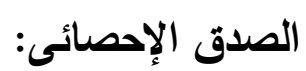

للتحقق من صدق مقياس قلق الاختبار باستخدام التابلت تم إجراء التحليل العاملي التوكيدي لمصفوفة

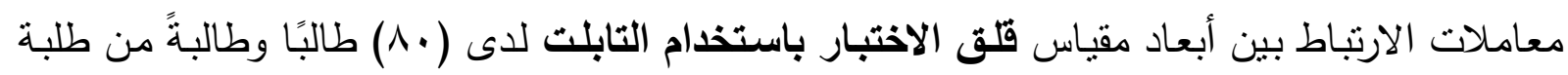

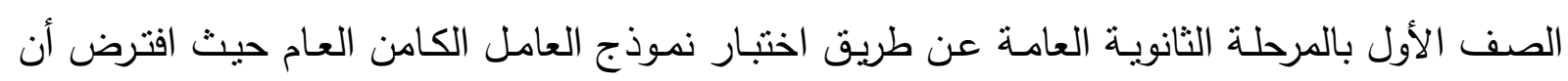

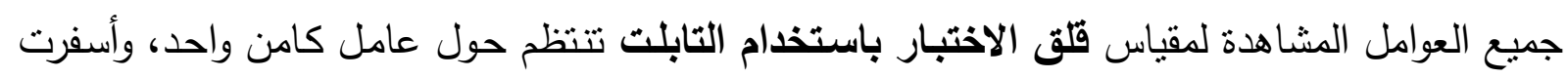

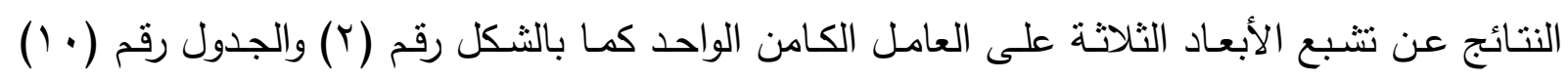




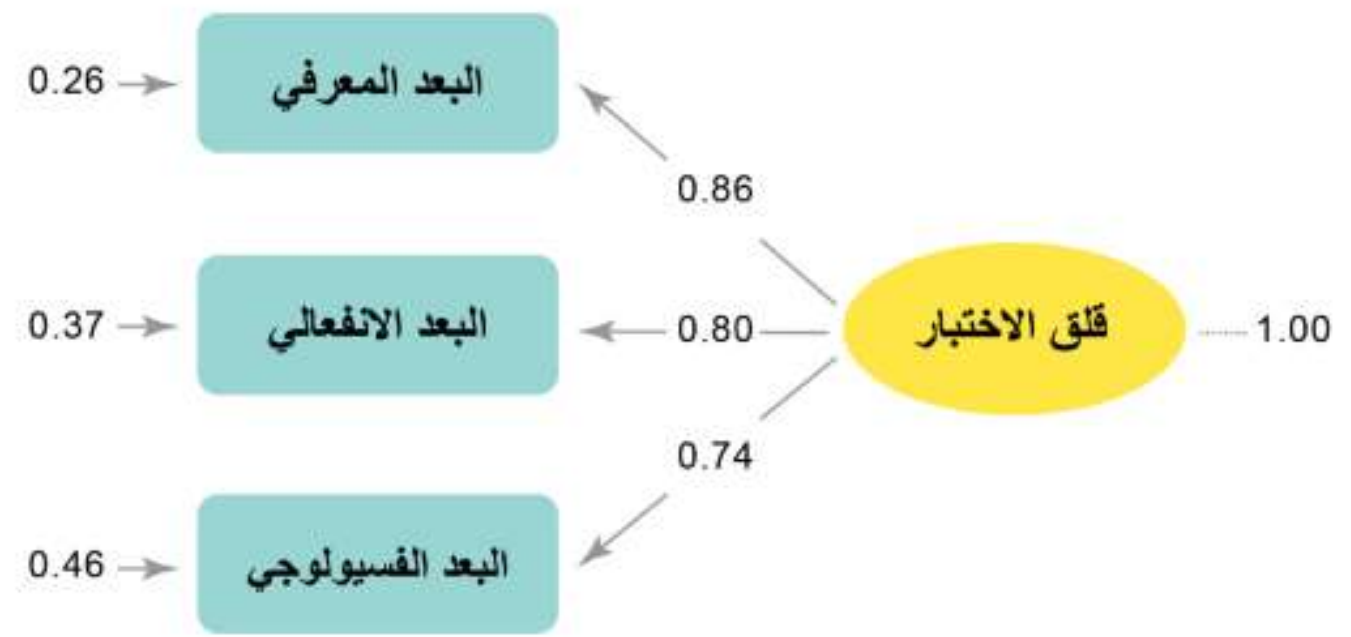

\section{Chi-Square $=0.00, d f=0, P$-value $=1.00000$, RMSEA $=0.000$}

شكل (1): المسار التخطيطي لنموذج التحليل العاملي التوكيدي لأبعاد مقياس قلق الاختبار باستخدام التابلت ويتضمن الثكل رقم (1) السابق تشبعات المتغيرات المشاهدة الثلاثثة بالعامل الكامن وهي تلك المقادير قرينـة الأسـهم الخارجـة مـن العامـل الكـامن والمتجهـة إلى المتغيـرات المشـاهدة (البعد المعرفي - البعد الانفعالي - البعد الفسيولوجي) أما المقادير المقابلة للأسهم المتجهة إلى المتغيرات المشاهدة جهة اليسار فإنها توضتح تباينات الخطأ في تقدير هذه المتغيرات المشاهدة، والواحد الصحيح بجوار السهم المتّجه إلى العامل الكامن من جهة اليمين يوضح معامل الارتباط للمتغيرات المستقلة في النموذج وهو عامل واحد

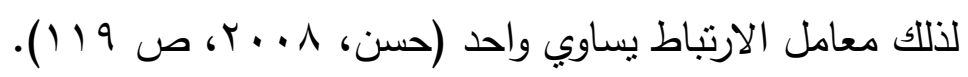
جدول ( ) : نتائج التحليل العاملي التوكيدي لتثبعات الأبعاد الثلاثة لقلق الاختبار باستخدام التابلت بالعامل الكامن العام

\begin{tabular}{|c|c|c|c|c|}
\hline معامل الثبات & قيمة (ت) & التقأ المعياري التثبع & معامل المسار & أبعاد قلق الاختبار \\
\hline$\because V Y \Lambda$ & $* * \mid r . \leqslant q Y$ & $\cdot .94$ & $\because \wedge \bullet q$ & البعد المعرفي \\
\hline . & $* * 1 r .119$ & .70 & $\because \vee 990$ & البعد الانفعالي \\
\hline$\cdot 0 \leqslant r$ & $* * 11.97 \mathrm{~V}$ & .977 &.$V T V$ & البعد الفسيولوجي \\
\hline
\end{tabular}

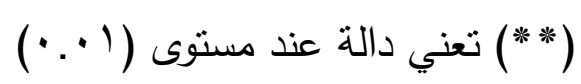

ويتضـح من الجدول رقم (1) السـابق أن كل التشبعات أو معاملات الصدق دالة إحصـائًا عند مستوى ( ( . . )، ممـا يدل على صدق جميع الأبعاد المكونـة للمقياس، ويلاحظ أن البعد المعرفي هو أفضل دئل 
مؤشر صدق للمتغير الكامن (قلق الاختبار باستخدام التابلت) حيث إن معامل نشبعه كان (109. . )

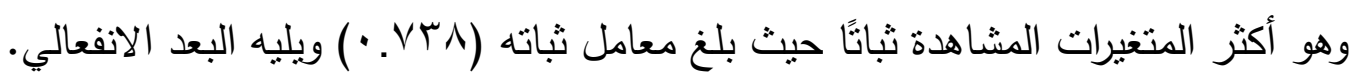
وكذلك أشارت النتائج إلى صدق هذا النموذج حيث حقق مؤشرات حسن مطابقة جيدة، وكانت قيمة كا'بَ

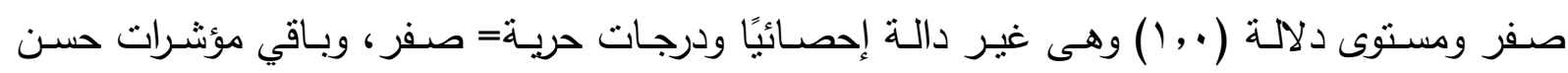
المطابقة تقع في المدى المثالي لها. وهذا يدل على مطابقة النموذج الجيدة للبيانات موضع الاختبار . ثانيًا: حساب ثبات مقياس قلى الاختبار باستخدام التابلت: وتم حساب الثبات بطريقتين كالتالي: أ- عن طريق معامل ثبات "ألفا- كرونباخ": نم حساب ثبات الأبعاد الفرعية والثبات الكلي لمقياس قلق الاختبار باستخدام التابلت، باستخدام معامل ألفا لـ "كرونباخ"، والجدول التالي رقم (ץ) يوضح ذلك: جدول (r): معاملات ثبات أبعاد مقياس قلق الاختبار باستخدام التابلت

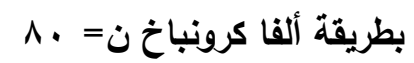

\begin{tabular}{|c|c|c|c|c|c|}
\hline \multicolumn{2}{|c|}{ البعد الفسيولوجي } & \multicolumn{2}{|c|}{ البعد الانفعالي } & \multicolumn{2}{|c|}{ البعد المعرفي } \\
\hline معامل دألفا بعد & المفردة & مدامل دألفا بعد & المفردة & مذف دامل ألفا بعد & المفردة \\
\hline$\because V 70$ & r & $\cdot v \leqslant r$ & r & $\cdot V \leqslant \Lambda$ & 1 \\
\hline$\because V Y V$ & 7 & צ & 0 & $\because V \leqslant r$ & $\varepsilon$ \\
\hline.$V{ }^{\prime}$ & 9 & $\because V Y q$ & $\wedge$ & $\because v 00$ & V \\
\hline$\cdot .7 V$. & Ir & $\because V O \leq$ & 11 & $\because \vee q$. & 1. \\
\hline 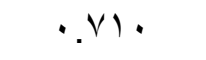 & 10 & & $1 \varepsilon$ & $\because \vee \backslash 9$ & Tr \\
\hline$\because V T V$ & معامل & $\because V 79$ & معامل ألفا & $\because \vee \vee 97$ & معامل \\
\hline
\end{tabular}

يتضح من الجدول رقم (r) السابق أن جميع مفردات أبعاد مقياس قلق الاختبار باستخدام التابلت (البعد المعرفي - البعد الانفعالي - البعد الفسيولوجي) تقل قيم معاملات ألفا لها بعد حذف درجة المفردة عن الن الهن

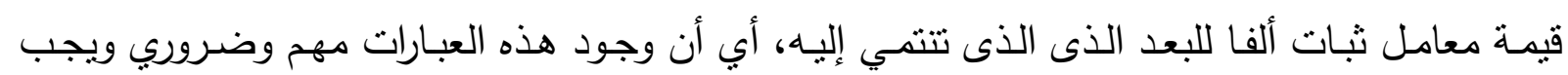
الإبقاء عليه ويدل على ثبات الأبعاد.

كما تم حساب معامل ثبات ألفا لـ "كرونباخ" للمقياس ككل فكانت قيمته= A9V. • وهي قيمة مرتفعة تدل على ثبات المقياس ككل خاصة وأن جميع قيم الثبات في حالة حذف درجة المفردة كانت أقل من أو هرئ تساوي قيمة ألفا العام.

ب - حساب ثبات قلث الاختبار باستخدام التابلت (الأبعاد والارجة الكلية) بطريقة "جتمان": 
تم حسـاب ثبات المقياس من خلال حسـاب ثبات أبعاد قلق الاختبـار باستخدام التابلت وكذلك بحسـاب الثبات للمقياس ككل باستخدام معامل "جتمان" وقد كان قيمة معامل الثبات للبعد الأول (البعد المعرفي) =

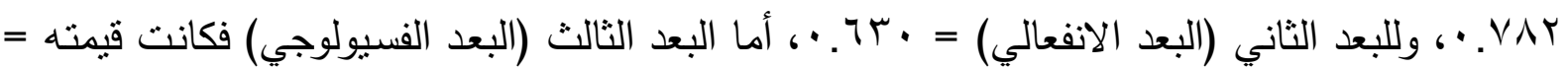

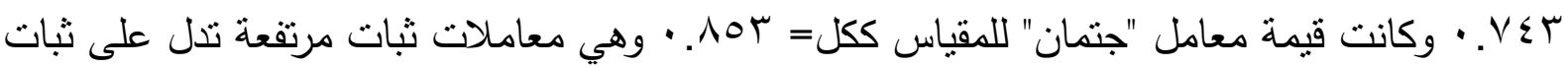
المقياس ككل وأبعاده الثلاثة.

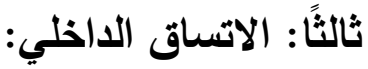
تم حساب معاملات الارتباط بين درجات العبارات، والدرجة الكلية للبعد الذي تتنمي إليه، كما تم حساب معامل الارتباط بين الدرجات والدرجة الكلية للمقياس. ووُجد أن جميع معاملات الارتباط دالة إحصائيًا عند مستوى دلالة ( ( . ·) كما يتضح من جدول رقم (r) التالي:

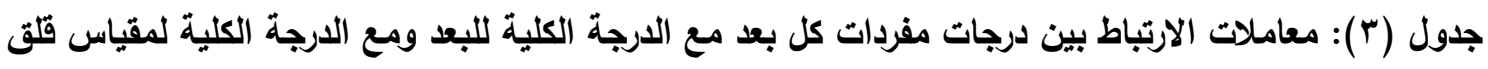
الاختبار باستخدام التابلث ن= .

\begin{tabular}{|c|c|c|c|c|c|}
\hline \multicolumn{2}{|c|}{ البعد الفسيولوجي } & \multicolumn{2}{|c|}{ البعد الانفعالي } & \multicolumn{2}{|c|}{ البعد المعرفي } \\
\hline الارنباط & المفردة & الارتباط & المفردة & الارتباط & المفردة \\
\hline$* *, .7 \cdot r$ & r & $* * .77 r$ & r & $* *, . \vee 71$ & 1 \\
\hline$* *, . \vee 19$ & 7 & $* *, . \wedge \varepsilon$. & 0 & $* * . . V \vee 1$ & $\varepsilon$ \\
\hline$* * .79$. & 9 & $* *, . V \cdot r$ & $\wedge$ & **. . VTV & V \\
\hline$* * . \Lambda Y r$ & ir & $* * .7 \leqslant V$ & 11 & $* * .7 \leq \varepsilon$ & 1. \\
\hline$* *, . \vee 01$ & 10 & $* * . V \leqslant V$ & $1 \varepsilon$ & **.AYr & rו \\
\hline
\end{tabular}

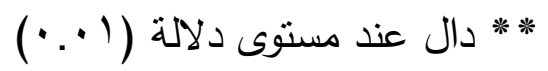

وبالإضافة لما سبق كان معامل الارتباط بين الدرجة الكلية لكل بعد من الأبعاد مع الدرجة الكلية للمقياس

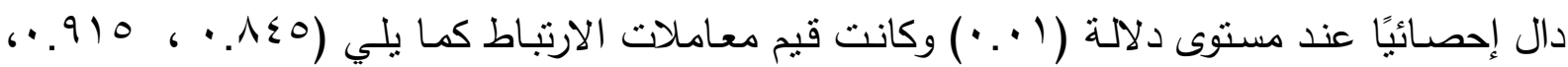

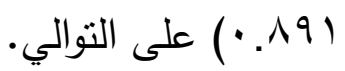

من الإجراءات السابقة تأكد للباحثين صلاحية مقياس قلق الاختبار باستخدام التابلت في صورته النهائية (المكون من: 10 مفردة) يمثلها ثلاثة أبعاد: البعد المعرفي، والبعد الانفعالي، والبعد الفسيولوجي للنطبيق

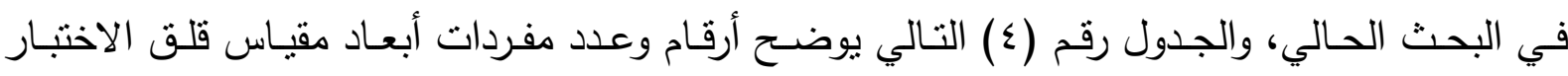
باستخدام التابلت. 
قلق الاختبار باستخدام التابلت لاى طلبة المرحلة الثانوية العامة

( د / إيناس محمد صفوت خريبة)

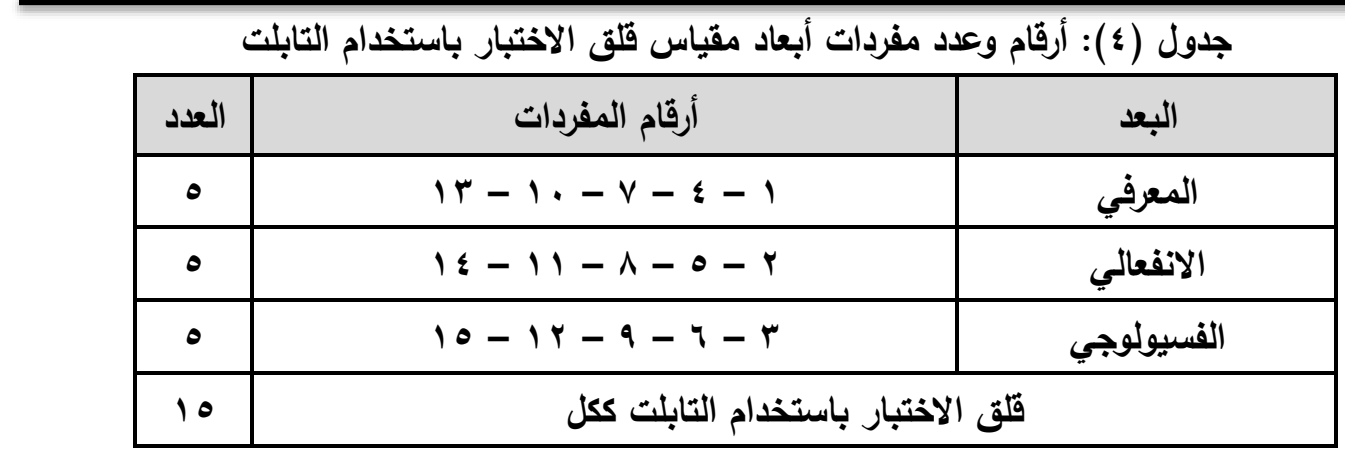

\section{نتائج البحث ومناقشتها وتفسيرها: - التحقق من اعتدالية توزيع البيانات:}

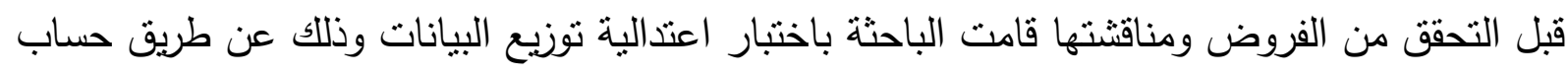

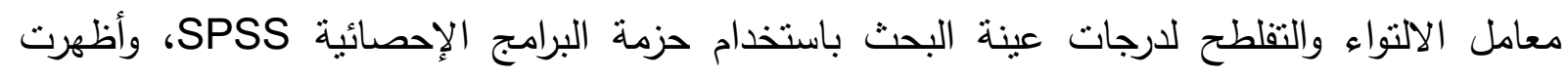

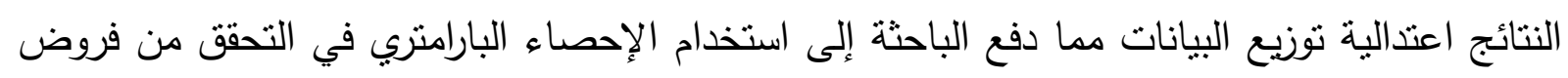
البحث.

نتائج الفرض الأول ومناقشتها وتفسيرها: ينص الفرض الأول على أنه "يوجد مستوى متوسط من قلتق الاختبار باستخدام التابلت لدى طلبـة المرحلة الثانوية العامة". جدول (•): المتوسطات والانحرافات المعيارية لأبعاد قلق الاختبار باستخدام التابلت والارجة الكلية له (ن= . ^)

\begin{tabular}{|c|c|c|c|c|}
\hline قلق الاختبار باستخدام التابلت ككل & البعد الفسيولوجي & البعد الانفعالي & البعد المعرفي & الأبعاد \\
\hline T.ro & 1.90 & T. $\leqslant 0$ & T.T & المتوسط \\
\hline . & .01 &..$\leqslant 7$ &..$\leqslant \wedge$ & الانحراف المعياري \\
\hline
\end{tabular}
وتم الحكم على مستوى التحقق من خلال ما يلي:

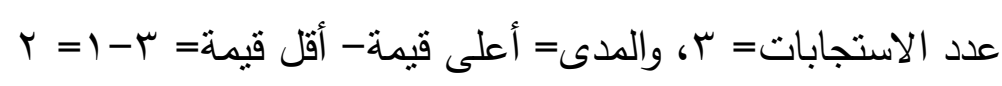

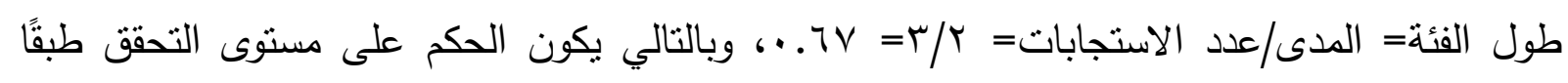

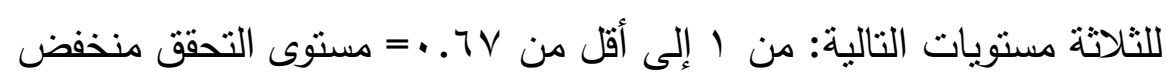

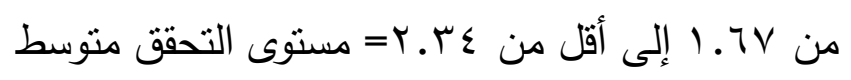

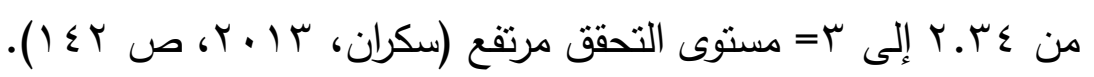
يتضح من نتائج الجدول السابق رقم (0) تحقق الفرض الأول حيث وجد مستوى منوسط من فلق الاختبار

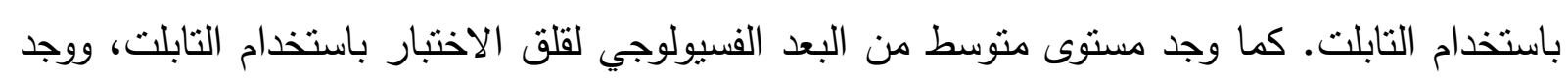
مستوى مرتفع من البعدين المعرفي والانفعالي له لدى طلبة المرحلة الثانوية العامة. 
ويمكن تفسير ذلك من خلا أن طلبة المرحلة الثانوية العامة على دراية كبيرة بالتعامل مع الأجهزة الإلكترونية والهواتف المحمولة، كما أن الانتقال من الصفين الأول والثاني الثانوي العام يتطلب النجاح فقط أي اجتياز الطالب بغض النظر عن حصوله على درجات مرتفعة من عدمه، فضلًا عن أن توافر بدائل لإجراء الاختبار في صورة ورقية ساهم في خفض مستوى قلق الطلبة نحو أداء الاختبار باستخدام التابلت والبعد الفسيولوجي له وجعلهما في مستوى متوسط قد يفسر وجود مستوى متوسط من قلق الاختبار باستخدام التابلت لدى طلبة المرحلة الثانوية. أما بالنسبة لوجود مستوى مرتفع من البعدين المعرفي والانفعالي من قلق الاختبار باستخدام التابلت فقد يرجع إلى أن أكثر ما يركز عليه الطالب أثناء التعلم هو الجانب المعرفي -وهو الأكثر تأثرًا بقلق بهاب الاختبار - حيث يحدث فقدان أو تداخل للمعلومات أثناء الاختبار، كما أن شعور الطالب بالخوف والتوتر قبل الاختبار وأثثائه قد يؤدي إلى فثنل استذعاء المعلومات؛ ومن ثم وجد مستوى مرتفع البعدين المعرفي والانفعالي لقلق الاختبار باستخدام التابلت.

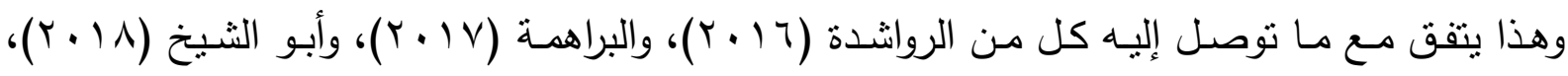

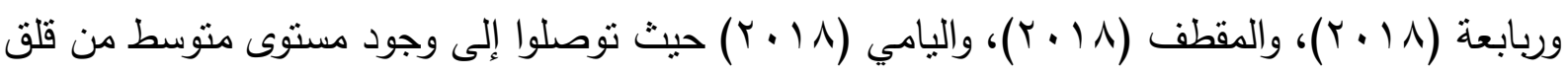
Vaz, Pothiyil, George, Alex, Pothiyil, \& الاختبار لدى عينة البحث، ويختلف مع نتائج بحث حيmath (2018)

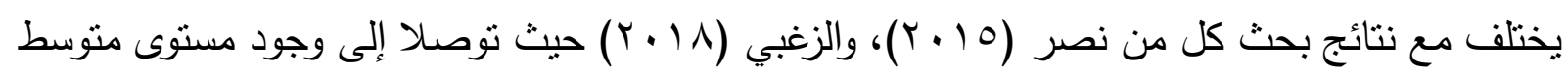

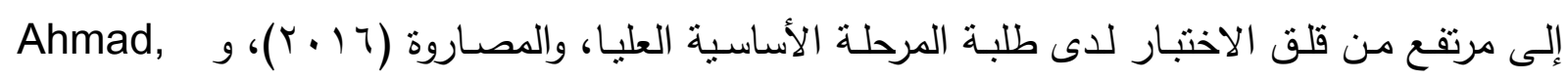
Al-Sahman (2019) ميث وجدوا مستوى مرتفع من قلق الاختبار . Hussain, \& Khan (2018)

\section{نتائج الفرض الثاني ومناقشتها وتفسيرها:}

ينص الفرض الثاني على أنـه "لا يختلف مستوى قلق الاختبـار باستخدام التابلت بـاختلاف نوع طلبـة المرحلة الثانوية العامة (ذكور - إناث)". جدول (†): نتائج اختبار (ت) للفروق في قلق الاختبار باستخدام التابلت وأبعاده بين الأكور والإناث

\begin{tabular}{|c|c|c|c|c|c|}
\hline قيمة (ت) ودلالتها & الانحراف المعياري & المتوسط & 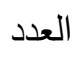 & النوع & البعد /المقياس \\
\hline \multirow[t]{2}{*}{$* r \ldots q$} & $\cdot . \Sigma V T$ & r.rVT & ع & ذكور & \multirow[t]{2}{*}{ البعد المعرفي } \\
\hline & $\cdot . \varepsilon \vee \leqslant$ & r. rVE & אדץ & 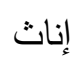 & \\
\hline \multirow[t]{2}{*}{.901} &..$\leqslant \wedge r$ & Y.EYI & ع & 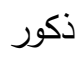 & \multirow[t]{2}{*}{ البعد الانفعالي } \\
\hline & $\cdot . \leqslant \leq \mu$ & Y.ETV & אדי & إناث & \\
\hline * ש.r. & .0997 & 1.119 & ITs & ذكور & البعد الفسيولوجي \\
\hline
\end{tabular}




\begin{tabular}{|c|c|c|c|c|c|}
\hline &. $.00 Y$ & Y.. 10 & אדצ & إناث & \\
\hline \multirow[t]{2}{*}{$* Y .0 \leqslant r$} &..$\varepsilon r V$ & r.IVI & $1 \pi \varepsilon$ & ذكور & قلق الاختبار باستخدام \\
\hline & ..$\leqslant r r$ & Y.YAT & זדז & إناث & التابلت ككل \\
\hline
\end{tabular}

يتضح من نتائج الجدول السابق رقم (0) عدم تحقق الفرض الثاني حيث تبين أنه لا توجد فروق تبعًا

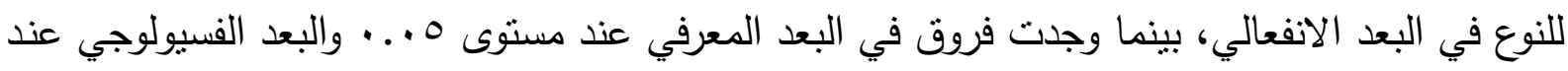
مستوى ( ... وفي الدرجة الكلية عند مستوى ه ... لصالح الإناث بالمرحلة الثانوية العامة.

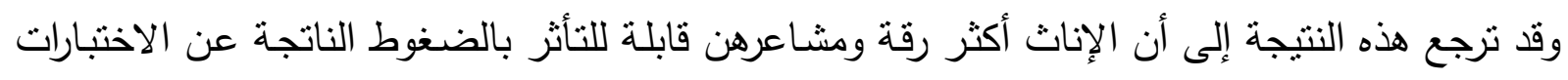

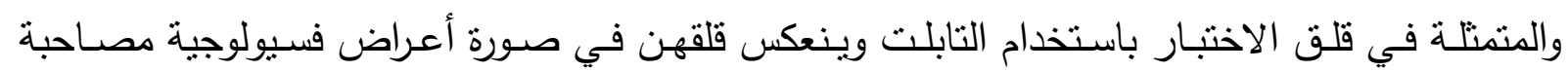
ونسيان المعلومات وتداخلها؛ ومن ثم كانت الفروق لصالح الإناث.

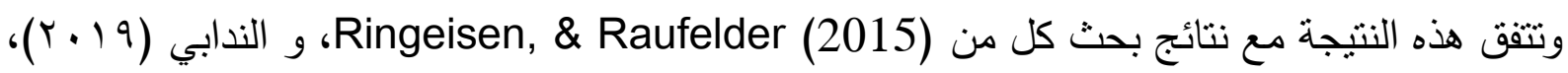

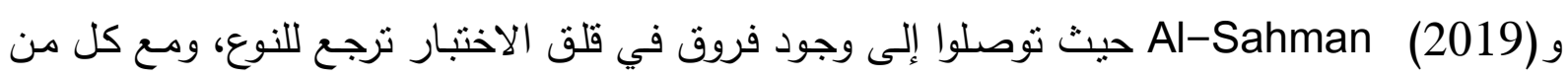

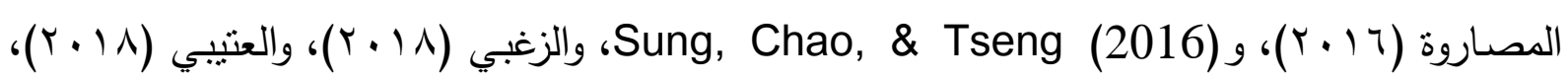

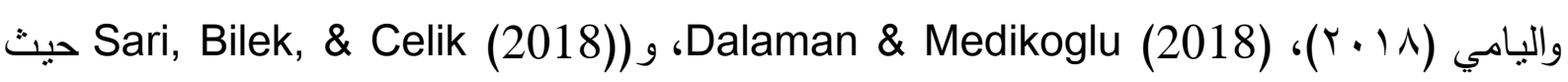
توصلوا إلى وجود فروق في مستوى قلق الاختبار تعزى للنوع لصالح الإناث.

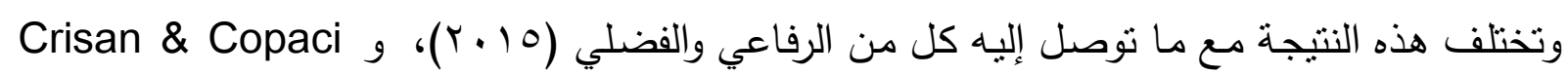

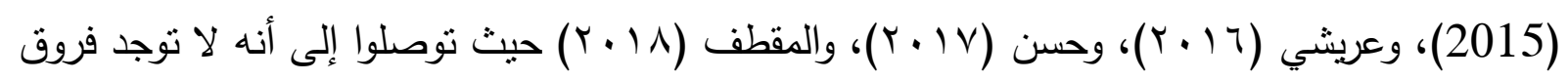

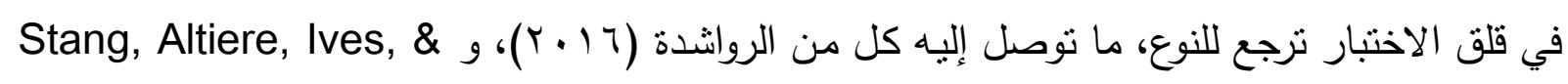

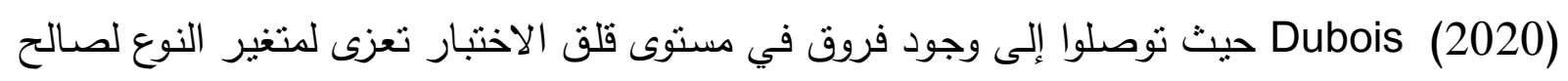

\section{نتائج الفرض الثالث ومناقشتها وتفسيرها:}

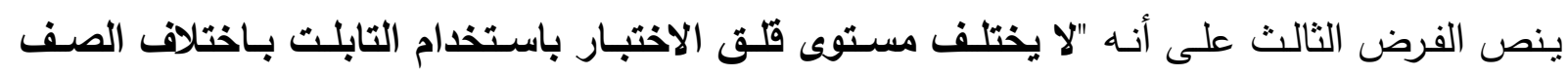
الاراسي لطلبة المرحلة الثانوية العامة (الأول - الثاني)". جدول (V): نتائج اختبار (ت) للفروق في قلق الاختبار باستخدام التابلت وأبعاده بين طلبة الصفين الأول والثاني

\begin{tabular}{|c|c|c|c|c|c|}
\hline قيمة (ت) ودلالتها & الانحراف المعياري & المتوسط & العدد & الفرقة & البعد /الدقياس \\
\hline \multirow[t]{2}{*}{.. $\varepsilon \cdot V$} &. .209 & T.TrA & $1 \leqslant 9$ & الأول & \multirow{2}{*}{ البعد المعرفي } \\
\hline & . . ¿^५ & $r . r \leqslant \Lambda$ & $r \leqslant \Lambda$ & الثاني & \\
\hline \multirow[t]{2}{*}{$\because V \backslash \leqslant$} & $. . \leqslant r \leqslant$ & T.\&VT & $1 \leq 9$ & الأول & \multirow[t]{2}{*}{ لبعد الانفعالي } \\
\hline &..$\Sigma V_{0}$ & r.\&५q & $r \leqslant \wedge$ & الثاني & \\
\hline
\end{tabular}




\begin{tabular}{|c|c|c|c|c|c|}
\hline \multirow[t]{2}{*}{$\because \vee q$} & $.0 \%$. & 1.94. & $1 \leq 9$ & الأول & \multirow{2}{*}{ البعد الفسيولوجي } \\
\hline & .7 .0 & $1.9 \times 7$ & $r \leq \Lambda$ & الثاني & \\
\hline \multirow[t]{2}{*}{.$r O \Lambda$} &.$r v$. & T.Y. & $1 \leq 9$ & الأول & \multirow{2}{*}{ قلق الاختبار باستخدام } \\
\hline & $\therefore \leqslant 7$ & r.rol & $r \leq \Lambda$ & الثاني & \\
\hline
\end{tabular}

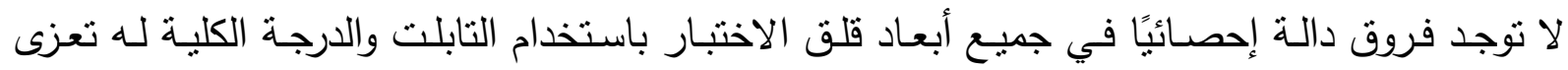
للصف الدراسي (الأول - الثاني) بالمرحلة الثانوية العامة.

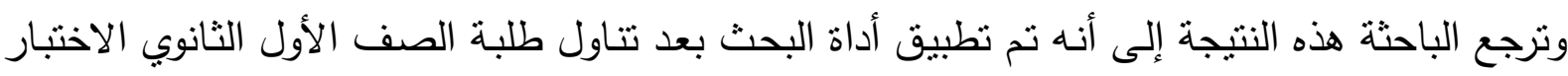

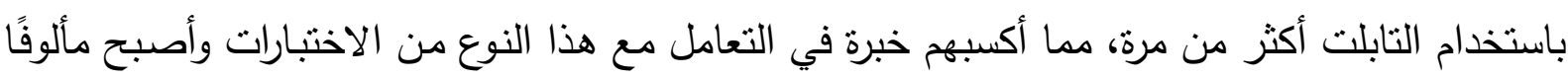

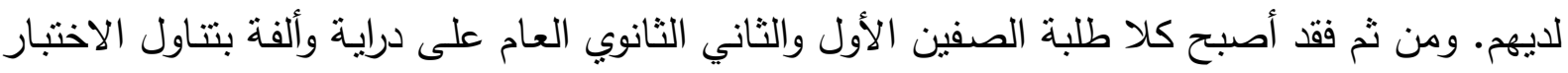

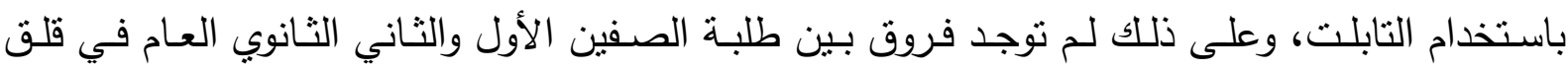
الاختبار باستخدام التابلت.

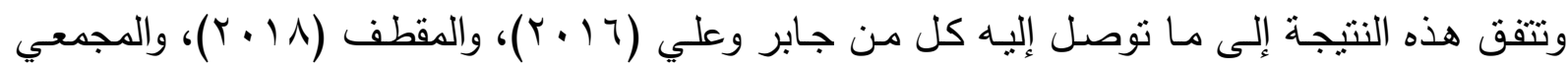

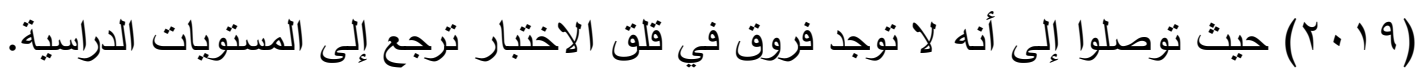

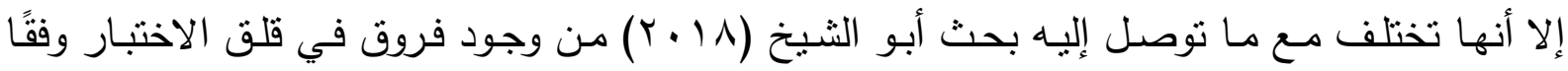
لمتغيرات المستوى التعليمي، وما نوصل إليه Dalaman \& Medikoglu (2018) من وجود ارتباط

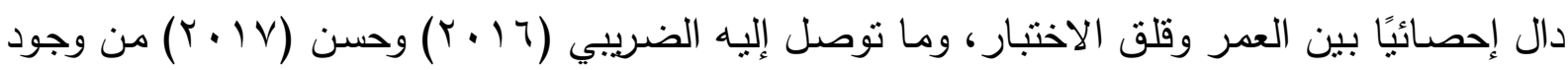

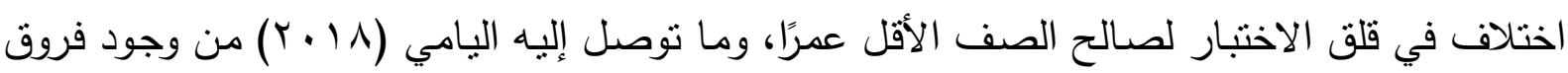

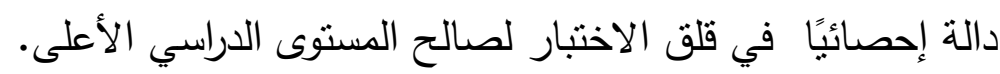
نتائج الفرض الرابع ومناقثتها وتفسيرها: ينص الفرض الرابع على أنه "لا يختلف مستوى قلث الاختبار باستخدام التابلت باختلاف مكان مدرسـة

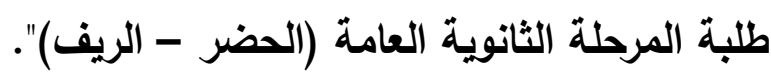
جدول (^): نتائج اختبار (ت) للفروق في قلق الاختبار باستخدام التابلت وأبعاده بين طلبة مدراس الحضر والريف

\begin{tabular}{|c|c|c|c|c|c|}
\hline قيمة (ت) ودلالتها & الانحراف المعياري & المتوسط & 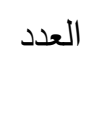 & الدرسة & البعد /الدقياس \\
\hline \multirow[t]{2}{*}{.079} &..$\varepsilon \wedge \varepsilon$ & T.MTT & 104 & حضر & \multirow{2}{*}{ البعد المعرفي } \\
\hline &. $.2 \vee v$ & r.rol & $r \leqslant \varepsilon$ & ريف & \\
\hline \multirow[t]{2}{*}{. } &. .579 & $r . \varepsilon r \Lambda$ & 104 & حضر & \multirow[t]{2}{*}{ لبعد الانفعالي } \\
\hline &..$\leq \leqslant \wedge$ & r. $\leqslant$. & $r \leq \varepsilon$ & ريف & \\
\hline
\end{tabular}




\begin{tabular}{|c|c|c|c|c|c|}
\hline \multirow[t]{2}{*}{.01.} &. .019 & 1.941 & 104 & حضر & \multirow{2}{*}{ البعد الفسيولوجي } \\
\hline & $.0 \times 1$ & 1.974 & $r \leq \varepsilon$ & ريف & \\
\hline \multirow[t]{2}{*}{ • } & . . & r.rT. & 104 & حضر & \multirow{2}{*}{ قلق الاختبار باستخدام } \\
\hline & ..डा। & r. rON & $r \leq \varepsilon$ & ريف & \\
\hline
\end{tabular}

لا توجد فروق دالة إحصائيًا في جميع أبعاد قلق الاختبار باستخدام التابلت والدرجة الكلية له تعزى لمكان المدرسة (حضر - ريف) لدى طلبة المرحلة الثانوية العامة.

وترجع الباحثة هذه النتيجة إلى أن وزارة التربية والتعليم قامت بتوفير تابلت خاص بكل طالب، كما عملت على تقوية شبكات الإنترنت في المدارس، ووفرت بدائل ورقية للاختبار في حال حدوث عطل بشبكة

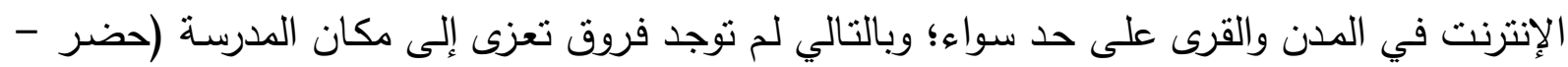
ريف) في قلق الاختبار باستخدام التابلت.

تختلف هذه النتيجة مع ما توصلت إليه نتائج بحث الندابي (9 ( ب م) من اختلاف مستوى قلق الاختبار

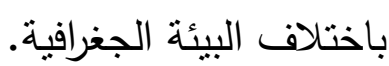

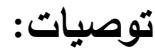

ا- توجيه المسئولين إلى ضرورة الاهتمام بكل ما ينسبب في إثارة القلق لاى طلبة المرحلة الثانوية العامة

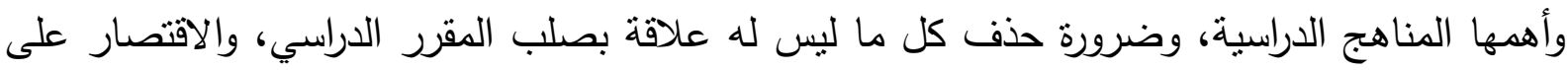

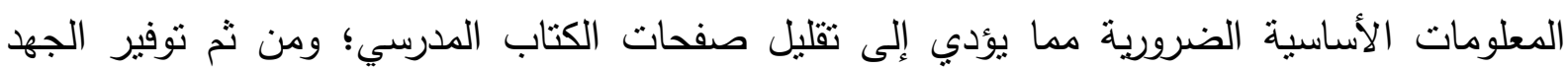
المبذول في الاستخكار وخفض قلق الاختبار لديهم.

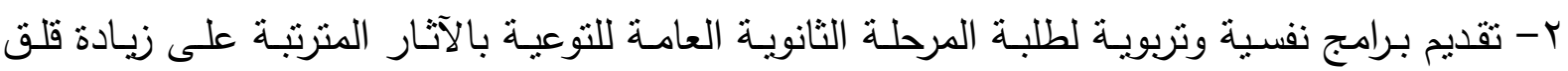
الاختبار وما قد ينتج عنه من أفكار سلبية تؤثنز على أدائهم في الاختبار وطرق خفضه هذا لفا القلق. r- تفعيل دور المعلم المرشد من خلال تزويده بدورات تدريبية نفسية وتربوية بما يتلاءم مع منطلبات

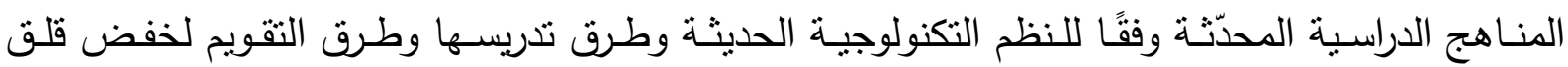

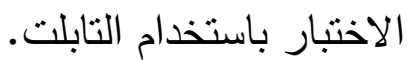
ع - تدريب طلبة الصفين الأول والثاني الثنانوي العام من خـال تتاول بعض الاختبارات الفصلية عن طريق التابلت لنزداد خبرتهم به مما يسهم في خفض قلق الاختبار لديهم عند أداء الاختبارات النهائية. 
ه- استحداث معايير للمفاضلة بين الطلبة عند الالتحاق بمختلف الكليات الجامعية وعدم الاقتصار على درجات الاختبارات مما يعمل على خفض قلق الاختبار لاى طلبة المرحلة الثانوية العامة.

البحوث المقترحة:

- قلق الاختبار باستخدام التابلت لدى طلبة المرحلة الثانوية العامة (دراسة طولية). - قلق الاختبار باستخدام التابلت وعلاقته بالأفكار اللاعقلانية لدى طلبة المرحلة الثانوية العامة. - قلق الاختبار باستخدام التابلت لدى طلبة المرحلة الثانوية العامة (أسبابه وطرق علاجه).

\section{المراج?}

أولًا: المراجع العربية

أبو الثيخ، عطية إسماعيل محمد (1) ( ب). قلق الاختبارات الإكترونية وعلاقته بالأداء في نظر عينة

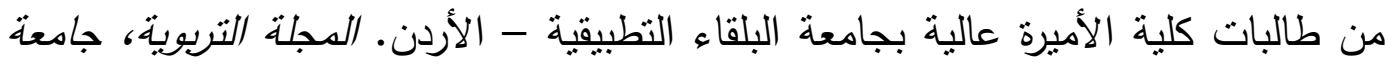

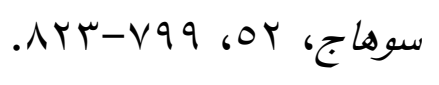

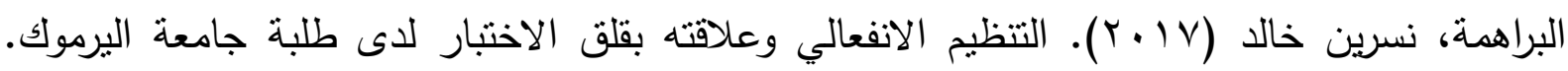
رسالة ماجستبر، جامعة اليرموك، الأردن.

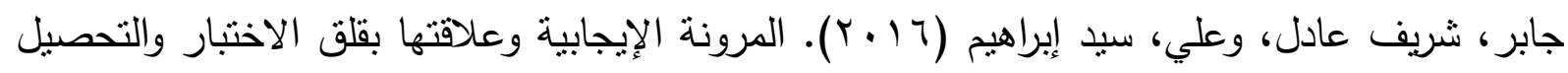

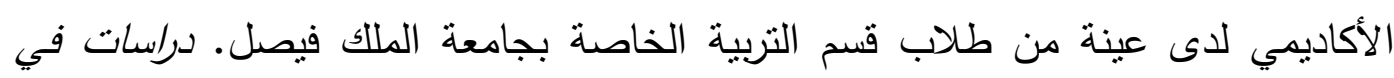

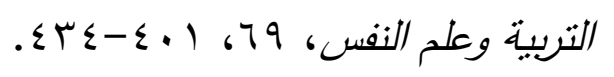

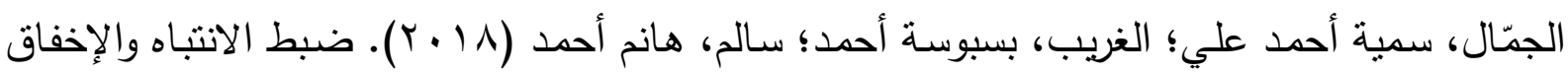

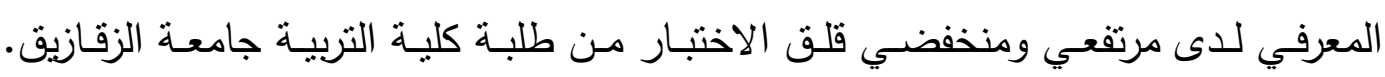

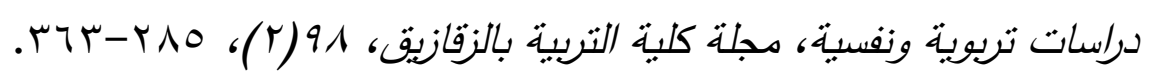

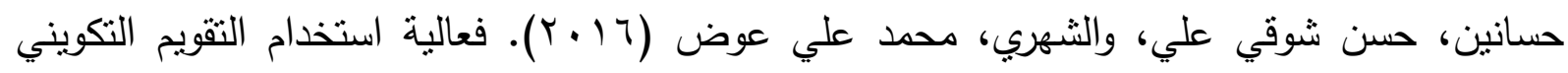

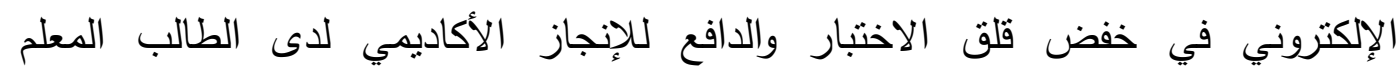

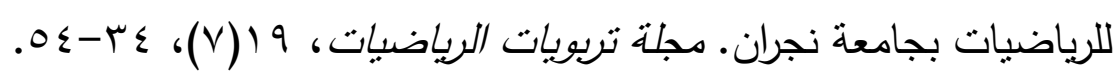

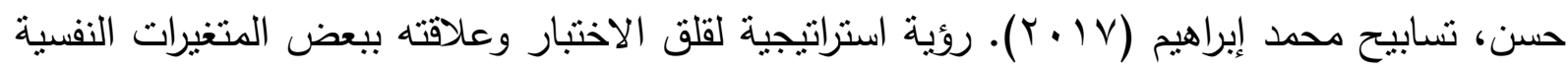

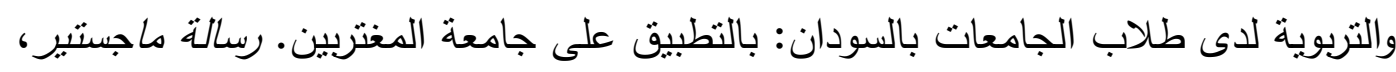

$$
\text { جامعة أم درمان الإسلامية، السودان. }
$$




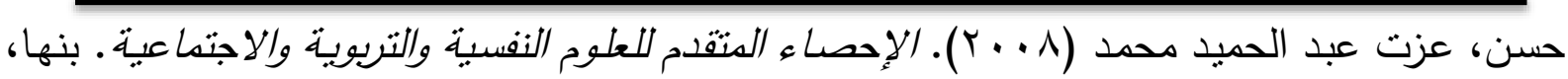
دار المصطفى للطباعة والنشر .

خريبه، إيناس محمد صفوت (10 ب r). قلق الاختبار الإلكتروني والاتجاه نحوه في ضوء كل من التحصيل الدراسي والتفضيل الاختباري لاى طالبات قسم علم النفس بكلية التربية. مجلة كلية

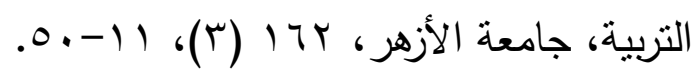

الدلالعة، أسامة محمد أمن أحمد، وعبابنة، زياد وليد محمد، والزبون، ماللك سليم عودة (9 ( • ( ). أثز الاختبارات الإلكترونية ونمط التفكير على التحصيل وقلق الاختبار والكفاءة الذاتية لاى طلبة

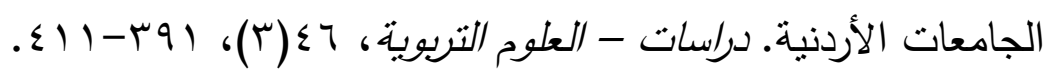

ربابعة، هثام عبد الحافظ (1 ( • ( ). المرونة النفسية وعلاقتها بقلق الاختبار لدى طلبة الجامعة الأردنية. رسالة ماجستبر، جامعة اليرموك، الأردن.

الرفاعي، تغريد، والفضلي، فضيلة جابر (10 • r). العلاقة بين عادات العقل وقلق الاختبار عند طلبة كلية التربية الأساسية بدولة الكوبت ضمن متغيرات مختارة. مجلة دراسات الطفولة،

$$
.11-11 ،(79) 11
$$

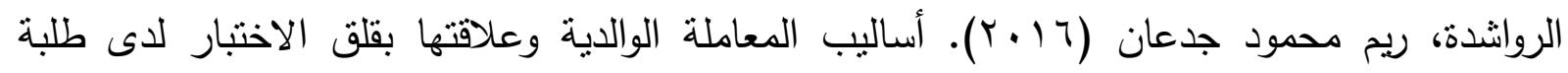
الثانوية في مدارس محافظة الكرك في الأردن. مجلة العلوم التربوبة، جامعة السودان للعلوم

$$
\text { والتنكنولوجيا ، }
$$

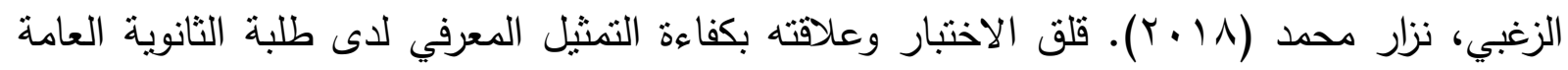
التوجيهي بلواء الكورة في الأردن. مجلة جامعة القد المفتوحة للأبحاث والدراسات التربوية

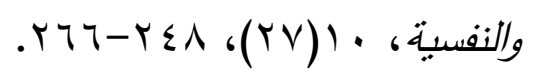

الثعفوري، علي بن شيخان (T ( . (Y). حقيبة معلم الاختبار الإكتروني. سلطنة عمان، وزارة التربية

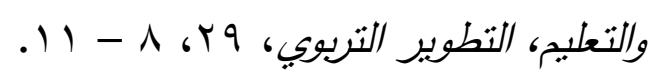

الضريبي، عبد الله محمد (T ( ب). دافعية الإنجاز وعلاقتها بقلق الاختبار والتحصيل الدراسي، وأثزها على التربية الأخلاقية لدى طلبة المرحلة الأساسية في محافظة البيضاء. مجلة دار العلوم،

$$
.07 \varepsilon-049694
$$

العبري، عبد الله علي محمد (Y V r r). أثر التقويم الإلكتروني في مستوى قلق الاختبار والتحصيل في مادة العلوم لدى طلاب الصف الثامن. رسالة ماجستبر، كلية التربية، جامعة السلطان

$$
\text { قابوس، عمان. }
$$




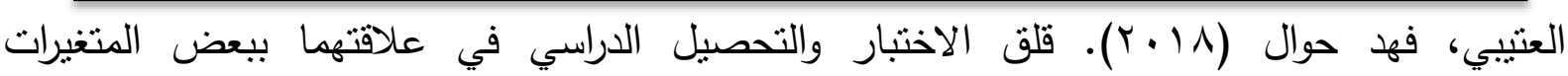
الديموجرافية لدى عينة من طلاب كلية التربية بعفيف بجامعة الثقراء. المجلة التربوبية،

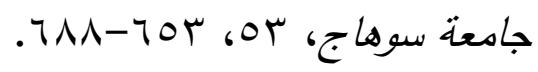

عريشي، صديق أحمد (T ( • ب). الإرجاء الأكاديمي وعلاقته بالكمالية وقلق الاختبار لدى طلاب المرحلة

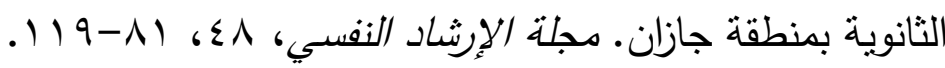

علي، أكرم فتحي مصطفى (9 . . r). أثز توظيف التذربب الإكتروني عبر شبكة الإنترنت في تتمية بعض مهارات تصميم الاخنبارات الإلكترونية لدى أعضاء هيئة التدريس بجامعة جنوب

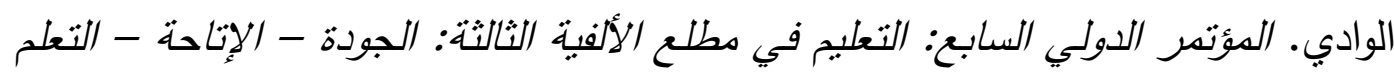

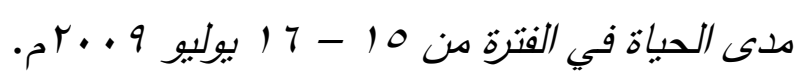

المجمعي، علي محمد مرعي (9 ( • (Y). علاقة دافعية الإنجاز الدراسي وقلق الاختبار لدى عينة من

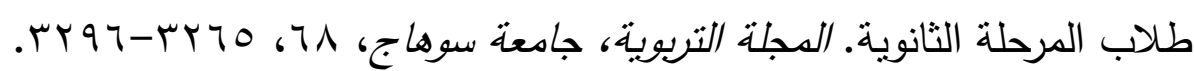

المصاروة، محمود مبارك سليم (7 ا • ب). العلاقة بين قلق الاختبار وأساليب التفكير لستيرنبرج لدى طلبة جامعة مؤتة. رسالة ماجستير، جامعة مؤتة، الأردن.

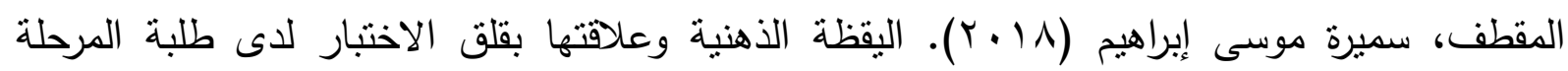
الثانوية في ليبيا. رسالة ماجستبر، كلية العلوم التربوية والنفسية، جامعة عمان العربية، الأردن.

الندابي، يوسف سالم سيف (9 ( ـ ( ). استراتيجيات التنظيم الانفعالي المعرفية وعلاقتها بقلق الاختبار لدى طلبة الجامعة: دراسة مقارنة بين طلبة جامعتي السلطان قابوس ومحمد الأول. مجلة

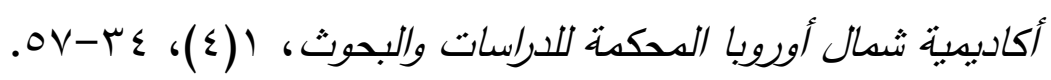

اليامي، محمد حسين فهيد (1 ( • (1). مستوى قلق الاختبار لدى طلبة المدارس الثانوية في تعليم مدينة نجران وسبل التغلب عليه. مجلة الجامعة الإسلامبة للاراسات التربوبة والنفسية، جب(ج)، .$\{91-\{07$

\section{ثانيًا: المراجع الأجنبية:}

Damer, D. E., \& Melendres, L. T. (2011). "Tackling test anxiety": A group for college students. The Journal for Specialists in Group Work, 36(3), $163-177$.

Brom, M. W. (2016). A correlational analysis of test anxiety and response time on a computerized adaptive math test among seventh grade students 
قلق الاختبار باستخدام التابلت لدى طلبة المرحلة الثانوية العامة

( د / إيناس محمد صفوت خريبة)

by gender. $A$ dissertation presentd in partial fulfillment of the requirements for the degree Doctor of Education, Liberty University.

van Lent, G. (2009). Risks and benefits of CBT versus PBT in high-stakes testing: Introducing key concerns and decision making aspects for educational authorities, 83-91. In: F. Scheuermann \& J. Björnsson (Eds.) The transition to computer-based assessment. New approaches to skills assessment and implications for large-scale testing, European Communities.

Hettiarachchi, E., Huertas, M. A., \& Mor, E. (2013). Skill and knowledge eassessment: A review of the state of the art [online working paper]. (Doctoral Working Paper Series; DWP 13-002). IN3 Working Paper Series.IN3 (UOC). http://journals.uoc.edu/ojs/index.php/in3working-paper-series/article/view/n13-hettiarachchi-huertasmor/n13-hettiarachchci-huertas-mor-en

Kyllonen, P. C. (2009). New constructs, methods, \& directions for computerbased assessment, 151-156. In: F. Scheuermann \& J. Björnsson (Eds.) The transition to computer-based assessment. New approaches to skills assessment and implications for large-scale testing, European Communities.

Carr, A. M. (2016). An exploratory study of test anxiety as it relates to the National Clinical Mental Health Counseling examinations. $A$ dissertation submitted in partial submitted in partial fulfillment of the requirements for the degree of Doctor of Philosophy inn Curriculum and Instruction with an emphasis in Counselor Education, College of Education, University of South Florida. 
قلق الاختبار باستخدام التابلت لاى طلبة المرحلة الثانوية العامة

( د / إيناس محمد صفوت خريبة)

Javanbakht, N. \& Hadian, M. (2014). The effects of test anxiety on learners' reading test performance. Procedia - Social and Behavioral Sciences, 98, 775-783.

Mohamadi, M., Alishahi, Z., \& Soleimani, N. (2014). A study on test anxiety and its relationship to test score and self-actualization of academic EFL students in Iran. Procedia - Social and Behavioral Sciences, 98, $1156-1164$.

Ahmad, N., Hussain, S., \& Khan, F. N. (2018). Test anxiety: Geder ad academic achievements of university students. Journal Postgrad Med Inst, 32(3), 295-300.

Al-Sahman, L. A., Al-Sahman, R. A., Joseph, B., \& Javali, M. A. (2019). Major factors causing examination anxiety in undergraduate dental studets - A questionnaire based cross-sectional study. Annals of Medical and Health Science Research, 9(6), 691-694.

Cipra, C., \& Muller-Hilke, B. (2019). Testing anxiety in andergraduate medical students and its correlation with different learning approaches. PLOS ONE, https://doi.org/10.1371/journal.pone.0210130, 1-11.

Crisan, C., \& Copaci, I. (2015). The relationship between primary school childrens' test anxiety and academic performance. The $\sigma^{\text {th }}$ International Conference Edu World 2014 "Education facing contemporary world issues", $7^{\text {th }}-9^{\text {th }}$ November 2014, Procedia Social and Behavioral Sciences, 180, 1584-1589.

Dalaman, O. \& Medikoglu, O. (2018). Examinations of test anxiety level of 1013 year old students: The case of Kayseri. International Journal of Eurasia Social Sciences, 9(31), 792-807.

Lotz, C., \& Sparefeldt, J. R. (2017). Does test anxiety increase as the exam draws near? - Students' state test anxiety recorded over the course 
قلق الاختبار باستخدام التابلت لاى طلبة المرحلة الثانوية العامة

of one semester. Personality and Individual Differences, 104, 397400 .

Mano, K. E. J., Gibler, R. C., Mano, Q. R., \& Beckmann, E. (2018). Attentional bias toward school-related academic and social threat among test-anxious undergraduate students. Learning and Individual differences, 64, 138-146.

Martin, R. D., \& Naziruddin, Z. (2020). Systematic review of student anxiety and performance during objective structured clinical examinations. Currents in Pharmacy Teaching and Learning. https://doi.org/10.1016/j.cptl.2020.07.007.

Morosanova, V., Fomina, T., \& Filippova, E. (2020). The relationship between the conscious self-regulation of schoolchildren's learning activity, their test anxiety level, and the final exam result in mathematics. Behavioral Sciences, 10(16), http://dx.doi.org/10.3390/bs10010016, 1-10.

Ringeisen, T. \& Raufelder, D. (2015). The interplay of parental support, parental pressure and test anxiety - Gender differences in adolescets. Journal of Adolescece, 45, 67-79.

Sung, Y.-T. Chao, T.-Y., \& Tseng, F.-L. (2016). Reexamining the relationship between test anxiety and learning achievement: An individual-differences perspective. Contemporary Educational Psychology, 46, 241-252.

Sari, S. A., Bilek, G., Celik, E. (2018). Test anxiety and self-esteem in senior high school students: a cross-sectional study. Nordic Journal of Psychiatry, 72(2), 84-88.

Stang, J. B., Altiere, E., Ives, J., \& Dubois, P. (2020). Exploring the contributions of self-efficacy and test anxiety to gender differences in 
قلق الاختبار باستخدام التابلت لدى طلبة المرحلة الثانوية العامة

( د / إيناس محمد صفوت خريبة)

assessments. http://arxiv.org/abs/2007.07947, Cornall University Library arXiv.org.

Vaz, Pothiyil, George, Alex, Pothiyil, \& Kamath (2018). Factors influencing examination anxiety among undergraduate nursing students: An exploratory factor analysis. Journal of Clincal and Diagnostic Research, 12(7), 16-19. 